\title{
Caffeine has a dual influence on NMDA receptor-mediated glutamatergic transmission at the hippocampus
}

\author{
Robertta S. Martins 1,2 (D) Diogo M. Rombo $^{1,3}$ (D) - Joana Gonçalves-Ribeiro ${ }^{1,3}$ (D) Carlos Meneses $^{4}$ (D) \\ Vladimir P. P. Borges-Martins ${ }^{2}$ (D) - Joaquim A. Ribeiro ${ }^{1,3}$ (D) Sandra H. Vaz ${ }^{1,3}$ (D) Regina C. C. Kubrusly ${ }^{2}$ (D) \\ Ana M. Sebastião ${ }^{1,3}$ (i)
}

Received: 19 June 2020 / Accepted: 20 August 2020 / Published online: 6 October 2020

(C) Springer Nature B.V. 2020

\begin{abstract}
Caffeine, a stimulant largely consumed around the world, is a non-selective adenosine receptor antagonist, and therefore caffeine actions at synapses usually, but not always, mirror those of adenosine. Importantly, different adenosine receptors with opposing regulatory actions co-exist at synapses. Through both inhibitory and excitatory high-affinity receptors $\left(A_{1} R\right.$ and $A_{2} R$, respectively), adenosine affects NMDA receptor (NMDAR) function at the hippocampus, but surprisingly, there is a lack of knowledge on the effects of caffeine upon this ionotropic glutamatergic receptor deeply involved in both positive (plasticity) and negative (excitotoxicity) synaptic actions. We thus aimed to elucidate the effects of caffeine upon NMDAR-mediated excitatory postsynaptic currents (NMDAR-EPSCs), and its implications upon neuronal $\mathrm{Ca}^{2+}$ homeostasis. We found that caffeine $(30-200 \mu \mathrm{M})$ facilitates NMDAR-EPSCs on pyramidal CA1 neurons from Balbc/ByJ male mice, an action mimicked, as well as occluded, by 1,3-dipropyl-cyclopentylxantine (DPCPX, $50 \mathrm{nM}$ ), thus likely mediated by blockade of inhibitory $\mathrm{A}_{1}$ Rs. This action of caffeine cannot be attributed to a pre-synaptic facilitation of transmission because caffeine even increased paired-pulse facilitation of NMDA-EPSCs, indicative of an inhibition of neurotransmitter release. Adenosine $\mathrm{A}_{2 \mathrm{~A}}$ Rs are involved in this likely pre-synaptic action since the effect of caffeine was mimicked by the $\mathrm{A}_{2 \mathrm{~A}} \mathrm{R}$ antagonist, $\mathrm{SCH} 58261(50 \mathrm{nM})$. Furthermore, caffeine increased the frequency of $\mathrm{Ca}^{2+}$ transients in neuronal cell culture, an action mimicked by the $\mathrm{A}_{1} \mathrm{R}$ antagonist, DPCPX, and prevented by NMDAR blockade with AP5 $(50 \mu \mathrm{M})$. Altogether, these results show for the first time an influence of caffeine on NMDA receptor activity at the hippocampus, with impact in neuronal $\mathrm{Ca}^{2+}$ homeostasis.
\end{abstract}

Keywords Caffeine $\cdot \mathrm{NMDAR} \cdot$ Hippocampus $\cdot \mathrm{A}_{1}$ adenosine receptor $\cdot \mathrm{A}_{2 \mathrm{~A}}$ adenosine receptor

\author{
Abbreviations \\ $\mathrm{A}_{1} \mathrm{R}$ \\ $\mathrm{A}_{2 \mathrm{~A}} \mathrm{R}$ \\ $\mathrm{aCSF}$ \\ Adenosine $A_{1}$ receptor \\ Adenosine $\mathrm{A}_{2 \mathrm{~A}}$ receptor \\ Artificial cerebrospinal fluid \\ Ana M. Sebastião \\ anaseb@medicina.ulisboa.pt \\ 1 Instituto de Farmacologia e Neurociências, Faculdade de Medicina \\ da Universidade de Lisboa, Lisbon, Portugal \\ 2 Laboratório de Neurofarmacologia, Departamento de Fisiologia e \\ Farmacologia, Pós-Graduação em Neurociências, Universidade \\ Federal Fluminense, Niterói, Brazil \\ 3 Instituto de Medicina Molecular João Lobo Antunes, Faculdade de \\ Medicina da Universidade de Lisboa, Lisbon, Portugal \\ 4 Área Departamental de Engenharia de Electrónica e \\ Telecomunicações e de Computadores, Instituto Superior de \\ Engenharia de Lisboa, Lisbon, Portugal
}

AD
AMPAR

AP5

ARs

CA1

$\mathrm{Ca}^{2+}$

CNQX

CNS

DIC

DIC-IR

DPCPX

EDTA

EPSCs

F340/380
Alzheimer's disease

$\alpha$-Amino-3-hydroxy-5-methyl-4isoxazolepropionic acid receptor

DL-2-Amino-5-phosphonopentanoic acid Adenosine receptors

Cornu Ammonis 1

Calcium ion

6-Cyano-7-nitroquinoxaline-2,3-dione

disodium salt hydrate

Central nervous system

Day in culture

Differential interference contrast-infrared

8-Cyclopentyl-1,3-dipropylxanthine

Ethylenediaminetetraacetic acid

Excitatory post-synaptic currents

Ratio from excitation wavelength $340 \mathrm{~nm}$ and $380 \mathrm{~nm}$ 


$\begin{array}{ll}\text { FBS } & \text { Fetal bovine serum } \\ \text { fEPSP } & \text { Field excitatory post-synaptic potential } \\ \text { GABA } & \text { Gamma-aminobutyric acid } \\ \text { HBSS } & \text { Hank's balanced salt solution } \\ \text { LTD } & \text { Long-term depression } \\ \text { LTP } & \text { Long-term potentiation } \\ \text { mGluR } & \text { Metabotropic glutamate receptors } \\ \text { NMDA } & \text { N-Methyl-D-aspartate } \\ \text { NMDAR } & \text { N-Methyl-D-aspartate receptor } \\ \text { N M D A R } ~ & \text { N-Methyl-D-aspartate receptor } \\ \text { EPSCs } & \text { excitatory post-synaptic potential } \\ \text { PDL } & \text { Poly-D-lysine } \\ \text { PPF } & \text { Paired-pulse facilitation } \\ \text { S.E.M. } & \text { Standard error of the mean }\end{array}$

\section{Introduction}

Caffeine is a psychoactive drug widely consumed in the world and has a plethora of actions in the central nervous system (CNS) [1]. Nowadays, in addition to traditional beverages such as coffee and tea, caffeine can be found in energy drinks, soft drinks, and chocolates $[2,3]$. The consumption of these products increased in recent years, including in children and adolescents [4-6], and may even exceed the recommended daily intake ( $2.5 \mathrm{mg} / \mathrm{kg}$ for $6-12$ years old children) due to advertisements designed to attract these young consumers [7-9].

Caffeine is a methylxanthine with several mechanisms of action, such as non-selective antagonism of adenosine receptors, as the high-affinity $A_{1}$ and $A_{2 A}$ adenosine receptor $\left(A_{1} R\right.$ and $A_{2 A} R$ ) subtypes, inhibition of cyclic nucleotide phosphodiesterases, mobilization of $\mathrm{Ca}^{2+}$ from the sarcoplasmic reticulum or inhibition of its reuptake, inhibition of monoamine oxidase and cyclooxygenase enzymes, and blockade of $\mathrm{GABA}_{\mathrm{A}}$ receptors $[2,10-15]$.

Adenosine $A_{1} R$ and $A_{2 A} R$ are widely distributed in the CNS. The $A_{1} R$ is expressed in pre- and post-synaptic sites $[16,17]$ with its greatest expression on the cortex, cerebellum, and hippocampus $[16,18,19]$. The $\mathrm{A}_{2 \mathrm{~A}} \mathrm{R}$ is mostly expressed in the basal ganglia but it is also present in the cortex and hippocampus, with pre- and post-synaptic actions being reported [20-24].

Adenosine is a homeostatic regulator of neuronal function, and therefore the blockade of its receptors by caffeine impacts on central nervous system activity. This has been explored in the context of the putative therapeutic actions of caffeine. Indeed, since $\mathrm{A}_{2 \mathrm{~A}} \mathrm{R}$ can promote excitotoxicity, several studies have looked for neuroprotective effects of caffeine or related compounds in neurodegenerative diseases, including memory impairment observed in Alzheimer's disease (AD) or aging $[14,25,26]$. In addition, several studies have identified an effect of caffeine on synaptic plasticity, learning, and memory, which is usually observed after long-term caffeine treatment, and demonstrate an improvement in hippocampusdependent learning, short-term memory, and LTP, in animal models for AD, sleep deprivation, or aging [27-29].

The $A_{1} R$ antagonism is responsible for the excitatory effect of caffeine upon synaptic transmission, while $A_{2 A} R$ antagonism mediates the inhibitory action of caffeine upon synaptic plasticity $[28,30]$. N-methyl-D-aspartate receptor (NMDAR) is an ionotropic glutamate receptor involved not only in several forms of synaptic plasticity but also in excitotoxicity due to its $\mathrm{Ca}^{2+}$-permeable ion channel properties [31,32]. Direct evidence for post-synaptic modulation of hippocampal NMDA receptors by adenosine $A_{1} R$ has been obtained long ago [33, 34], while $A_{2 A} R$ has been recently reported as postsynaptic modulators of NMDA receptors at the hippocampus of young adult rats [24]. $A_{2 A} R$ is also known to interact with other neurotransmitter receptors to control NMDA receptor activity at the hippocampus [35-40].

The impact of adenosine $A_{1} R$ - and $A_{2 A} R$-mediated NMDA receptor modulation for neuroprotection, synaptic plasticity, learning, and memory has been repeatedly highlighted and discussed [24, 35, 41-46]. Since caffeine antagonizes $\mathrm{A}_{1} \mathrm{R}$ and $\mathrm{A}_{2 \mathrm{~A}} \mathrm{R}$, and since these receptors co-exist at different levels at the tripartite synapses, frequently having opposite roles in neuronal function, it is of uttermost importance to understand how this widely consumed substance modulates a receptor that also has a dual role on synapses. Therefore, the aim of this work was to evaluate the acute effect of caffeine on NMDAR-mediated currents of pyramidal neurons of the hippocampal Cornu Ammonis 1 region (CA1), as well as to evaluate the contribution of this action of caffeine on $\mathrm{Ca}^{2+}$ signaling in hippocampal neurons.

\section{Experimental procedures}

All experimental procedures were performed according to European Community Guidelines (Directive 2010/63/EU) and the Portuguese Law (DL 113/2013) for animal care for research purposes and were approved by the "Instituto de Medicina Molecular João Lobo Antunes" Internal Committee and the Portuguese Animal Ethics CommitteeDirecção Geral de Veterinária.

\section{Whole cell patch clamp recordings}

Young mice Balbc/ByJ males (PN35-48 days) were deeply anesthetized with isoflurane and euthanized by decapitation. The brain was quickly removed and hemispheres isolated for hippocampal dissection in $4{ }^{\circ} \mathrm{C}$ dissecting solution containing (in $\mathrm{mM}$ ) sucrose $110 ; \mathrm{KCl} 2.5 ; \mathrm{CaCl}_{2} 0.5 ; \mathrm{MgCl}_{2} 7 ; \mathrm{NaHCO}_{3}$ 25; $\mathrm{NaH}_{2} \mathrm{PO}_{4}$ 1.25; and glucose 7, $\mathrm{pH}=7.4$, aired with $95 \%$ $\mathrm{O}_{2}$ and $5 \% \mathrm{CO}_{2}$. Transversal hippocampal slices $(300 \mu \mathrm{m}$ thick) were made using a vibratome (Leica VT 1000S; Leica 
Microsystems, Germany) routinely in the laboratory (e.g., [24]). Slices were then incubated for $30 \mathrm{~min}$ at $35^{\circ} \mathrm{C}$ in artificial cerebrospinal fluid (aCSF) containing (mM) NaCl 124; $\mathrm{KCl} 3 ; \mathrm{NaH}_{2} \mathrm{PO}_{4} 1.25 ; \mathrm{NaHCO}_{3} 26 ; \mathrm{MgSO}_{4} 1 ; \mathrm{CaCl}_{2} 2$; and glucose $10, \mathrm{pH} 7.4$, gassed with $95 \% \mathrm{O}_{2}$ and $5 \% \mathrm{CO}_{2}$, and then allowed to further energetic recover at room temperature for at least $1 \mathrm{~h}$, before starting recordings. Throughout the recording period, the aCSF was supplemented with $5 \mu \mathrm{M}$ glycine and no $\mathrm{Mg}^{2+}$ was added.

For recordings, individual slices were fixed with a grid in a recording chamber and continuously superfused with modified aCSF (supplemented with $5 \mu \mathrm{M}$ glycine and no $\mathrm{Mg}^{2+}$ ) at room temperature by a gravitational superfusion system at 2 $3 \mathrm{~mL} / \mathrm{min}$. NMDAR-mediated synaptic currents were pharmacologically isolated with the addition of picrotoxin $\left(\mathrm{GABA}_{\mathrm{A}}\right.$ receptor blocker-50 $\left.\mu \mathrm{M}\right)$ and 6-cyano-7nitroquinoxaline-2,3-dione disodium salt hydrate (CNQX$\alpha$-amino-3-hydroxy-5-methyl-4-isoxazolepropionic acid receptor (AMPAR) blocker-10 $\mu \mathrm{M}$ ) to the perfusion medium (modified aCSF) during all recording time. Recorded signals were allowed to stabilize for at least $10 \mathrm{~min}$ before the addition of any test drug. Tested drugs were added to the superfusion solution; $0 \mathrm{~min}$ in the time-course figures indicate the time at which the changeover of solutions was initiated. When caffeine was tested in presence of other drug, caffeine wasadded to superfusionsolutionat $0 \mathrm{~min}$, whiletheotherdrug was added at least for $10 \mathrm{~min}$, before caffeine addition, during the baseline period, as indicated in the time-course figures. Wheneverchanging solutions, around 2-3 min elapsed before the new solution reaches the recording chamber.

Patch pipettes (4-9 M $\Omega$ ) were pulled from borosilicate glass capillaries (1.5-mm outer diameter, 0.86 inner diameter, Harvard Apparatus) with a PC-10 Puller (Narishige Group) and filled with an intracellular solution containing $(\mathrm{mM}) \mathrm{K}$ gluconate $125 ; \mathrm{KCl} 11 ; \mathrm{CaCl}_{2} 0.1 ; \mathrm{MgCl}_{2} 2$; EGTA 1 ; HEPES 10; MgATP 2; NaGTP 0.3; and phosphocreatine 10, pH 7.3, adjusted with $\mathrm{KOH}(1 \mathrm{M}), 280-290 \mathrm{mOsm}$. Electrode positioning and cell selection were performed under visual guidance using a Carl Zeiss Axioskop 2FS upright microscope (Jena, Germany) equipped with a differential interference contrast-infrared (DIC-IR) CCD video camera (VX44, Till Photonics, Gräfelfing, Germany).

Recordings from CA1 pyramidal cells were performed in voltage-clamp mode $(\mathrm{Vh}=-60 \mathrm{mv})$ with an Axopatch 200B amplifier (Axon Instruments, CA, USA). Excitatory post-synaptic currents (EPSCs) were electrically evoked every $15 \mathrm{~s}$ by an electric pulse delivered through a bipolar concentric electrode (Advent Research Materials) placed on the side fibers of Schaffer collaterals. For the pairedpulse facilitation (PPF) assessment, 2 pulses separated by $250 \mathrm{~ms}$ were delivered every $15 \mathrm{~s}$. The junction potential was not compensated for and offset potentials were nulled before giga-seal formation. Small voltage steps $(5 \mathrm{mV}$,
$50 \mathrm{~ms}$ ) were delivered throughout the experiment to monitor the access resistance; the holding current was also constantly monitored and when any of these parameters varied by more than $20 \%$, the experiment was rejected. The current signal was low-pass filtered using a $3-$ and $10-\mathrm{kHz}$ three-pole Bessel filter, digitized at $10 \mathrm{kHz}$ using a Digidata 1322A board, and registered by the Clampex software version 10.2 (Molecular Devices, Sunnyvale, CA, USA). Data analysis was performed with Clampfit 10 (included in pCLAMP 10).

\section{Primary culture of neurons}

Primary purified neuron cultures were prepared according to established methodology (e.g., [47]). Briefly, SpragueDawley fetuses (pre-natal day 18/19) were sacrificed and their brains used to grow primary neuronal cultures. The fetuses were collected in Hank's balanced salt solution (HBSS), their cerebral cortex together with the hippocampus was isolated, the meninges were removed, and the tissue was prepared for co-culture. The obtained tissues were mechanically fragmented and digested with $10 \%(\mathrm{v} / \mathrm{v})$ trypsinethylenediaminetetraacetic acid (EDTA) in HBSS for $15 \mathrm{~min}$ at $37^{\circ} \mathrm{C}$. Trypsin action was stopped with the addition of a solution with $30 \%(\mathrm{v} / \mathrm{v})$ fetal bovine serum (FBS) in HBSS, followed by $3 \times$ centrifugation at $1200 \mathrm{rpm}$ (Eppendorf, 5810R, Hamburg, Germany); in each cycle, the medium was discarded and renewed with $30 \%(\mathrm{v} / \mathrm{v})$ FBS in HBSS solution. After the last centrifugation, cells were resuspended in supplemented Neurobasal medium $(0.5 \mathrm{mM}$ L-glutamine, $25 \mu \mathrm{M}$ glutamic acid, 2\% (v/v) B-27, and $12 \mu \mathrm{g} / \mathrm{mL}$ gentamycin). Cells were strained through a nylon filter $(70 \mu \mathrm{m})$, and then $200 \mu \mathrm{l}$ of the supernatant with an average density of 5000 cells per well was plated in $9.4 \times 10.7 \times 6.8$ (mm) 8-well glass-bottom plates (ibidi GmbH, Martinsried, Germany) previously coated with Poly-D-lysine (PDL) for at least $2 \mathrm{~h}$ and washed 3 times with sterile water. Until the day of the experiments, the plated cells were maintained in a humid atmosphere $\left(5 \% \mathrm{CO}_{2}\right)$ at $37^{\circ} \mathrm{C}$ with $150 \mu \mathrm{l}$ of Neurobasal growth medium being added on the seventh day of culture (DIC).

\section{$\mathrm{Ca}^{2+}$ imaging}

$\mathrm{Ca}^{2+}$ signaling recordings from cultured neurons were done as before [48]. Ibidi plates were mounted on an inverted microscope (Axiovert 135TV, Zeiss) with a xenon lamp and 340$\mathrm{nm}$ and 380-nm wavelength bandpass filters. Throughout the experiment, the cells were kept at $37{ }^{\circ} \mathrm{C}$ in a humid atmosphere. During the first 5 min of the trial, baseline $\mathrm{Ca}^{2+}$ levels were established. Test drugs were then applied directly to the medium with a pipette. At the end of the experiment, the $\mathrm{Ca}^{2+}$ ionophore, ionomycin $(2 \mu \mathrm{M})$, was added and only the cells 
that clearly responded to ionomycin with a clear increase in the $340 / 380 \mathrm{~nm}$ ratio were considered for statistical analysis. Zero minutes in the time-course figures represent the time when recordings begun.

Image pairs were taken every $10 \mathrm{~s}$ with excitation wavelengths of 340 and $380 \mathrm{~nm}$ and then used to obtain respective ratio images. The excitation wavelengths were changed using a high-speed wavelength switch, Lambda DG-4 (Sutter Instrument, Novato, CA, USA), and the emission wavelength was set to $510 \mathrm{~nm}$. Image data were recorded by a CCD camera (Photometrics CoolSNAP fx) and processed and analyzed by MetaFluor software (Universal Imaging, West Chester, PA, USA). The regions of interest were obtained by profiling the cells and averaging fluorescence intensity within the delimited area. Intensity values were converted to the 340 / $380 \mathrm{~nm}$ ratio and all values in each cell were normalized to the first recorded ratio.

\section{$\mathrm{Ca}^{2+}$ imaging analysis}

The frequency of $\mathrm{Ca}^{2+}$ transients was determined with MATLAB and Statistics Toolbox Release 2016a, The MathWorks, Inc. (Natick, MA, USA), with a specific roadmap. In the first $5 \mathrm{~min}$ of the experiment, a baseline was obtained. Mean and standard error of the mean (S.E.M) of all data recorded by each cell was obtained. Transient validation was performed as described by [49] with some modifications. Cells that had spontaneous $\mathrm{Ca}^{2+}$ transients during the first $5 \mathrm{~min}$ of the experiment were discarded from the statistical analysis. For a $\mathrm{Ca}^{2+}$ transient to be considered valid, the following criteria had to be met: only if the fura-2 excitation wavelength $340-\mathrm{nm}$ and 380 $\mathrm{nm}(\mathrm{F} 340 / 380)$ ratio transient was greater than the mean of baseline values plus 15 times the S.E.M. of the baseline values that $\mathrm{Ca}^{2+}$ transient would be considered. In addition, the normalized ratio must be above this margin for more than $10 \mathrm{~s}$ and less than $700 \mathrm{~s}$. For each region of interest, the peak of each transient, as well as the occurrence of transients, was recorded.

\section{Statistical analysis}

The statistical analysis was obtained utilizing the software GraphPad Prism 6.01 (GraphPad Software, Inc.). The paired data with two data groups were analyzed using either Student's $t$ test or Wilcoxon matched-pairs signedrank test. Data with more than two groups analyzed were analyzed by a univariate or multivariate ANOVA followed by the Bonferroni post hoc test. The data are expressed as mean \pm S.E.M. For all tests, $p<0.05$ was considered to be statistically significant.

\section{Results}

\section{Caffeine enhances NMDAR-mediated synaptic cur- rents, an action mimicked by a selective $A_{1} R$ antagonist}

The effect of caffeine on synaptic currents mediated by NMDAR in CA1 hippocampal pyramidal neurons of adolescent mice is summarized in Fig.1. At a concentration $(200 \mu \mathrm{M})$ that fully blocks adenosine receptors $[11,12]$, it caused a fast and significant increase $(47 \pm 12 \%, n=16$ cells from 16 slices from 8 mice, $p<0.005$ ) in the amplitude of NMDAR-mediated currents (Fig. 1a,c). At this concentration, caffeine also affects other signaling mechanisms besides blockade of adenosine receptors, as inhibition of phosphodiesterases and $\mathrm{Ca}^{2+}$ release from intracellular stores, among others [11,12], which could be responsible for an excitatory action upon synaptic transmission. To find out whether the facilitation of NMDAR currents by caffeine could be attributed to antagonism of adenosine receptors, we designed three independent experiments aiming (1) to test the action of caffeine at a concentration $(30 \mu \mathrm{M})$ that, though submaximal in what respects adenosine receptor blockade, is known to cause minimal effects on phosphodiesterases or other signaling mechanisms [11, 12]; (2) to compare the action of caffeine with the action of a selective antagonist of the inhibitory $A_{1} R$ receptor; (3) to test whether the facilitatory action of caffeine could be occluded by previous blockade of adenosine $\mathrm{A}_{1} \mathrm{R}$.

Caffeine $(30 \mu \mathrm{M})$ also enhanced the peak amplitude of NMDAR-mediated EPSCs ( $\%$ increase: $47 \pm 16 \%, n=9$ cells from 9 slices from 5 mice, $p<0.03 \%$, Fig. 1a,c), the magnitude of the effect being similar to that obtained with $200 \mu \mathrm{M}$ (Fig. 1a,c). The selective $A_{1} R$ antagonist, DPCPX $(50 \mathrm{nM})$, also increased the amplitude of the NMDAR-mediated EPSCs (\% increase: $54 \pm 14 \%, n=6$ cells from 6 slices from 4 mice, $p<0.03 \%$ Fig. 1a, c), though with a slightly slower time course than caffeine (Fig. 1a). Importantly, in slices that had been previously incubated with DPCPX for 15 min before testing the effect of caffeine, this xanthine was unable to further facilitate NMDAR-mediated EPSCs (\% change of currents caused by caffeine in the presence of DPCPX: $1.8 \pm$ $8.4 \%, n=9$ cells from 9 slices from 5 mice Fig. 1b,c).

Altogether, these results indicate that the main mechanism operated by caffeine to increase NMDAR-mediated synaptic currents at the hippocampus is the blockade of $A_{1} R$. 

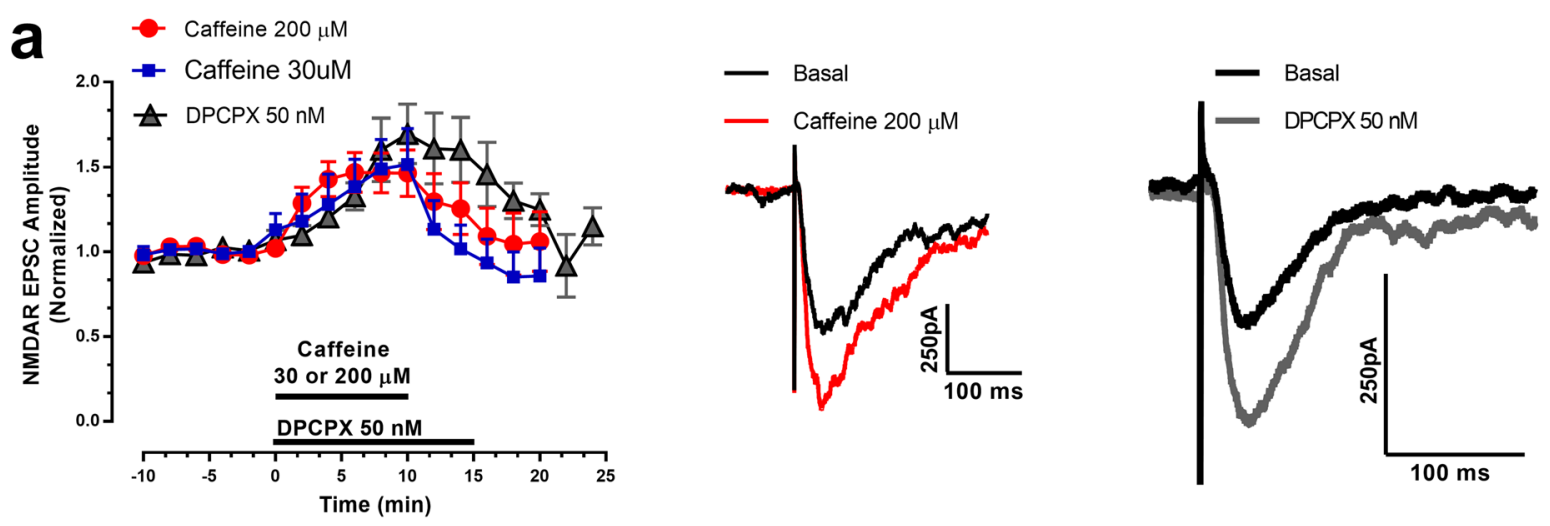

b
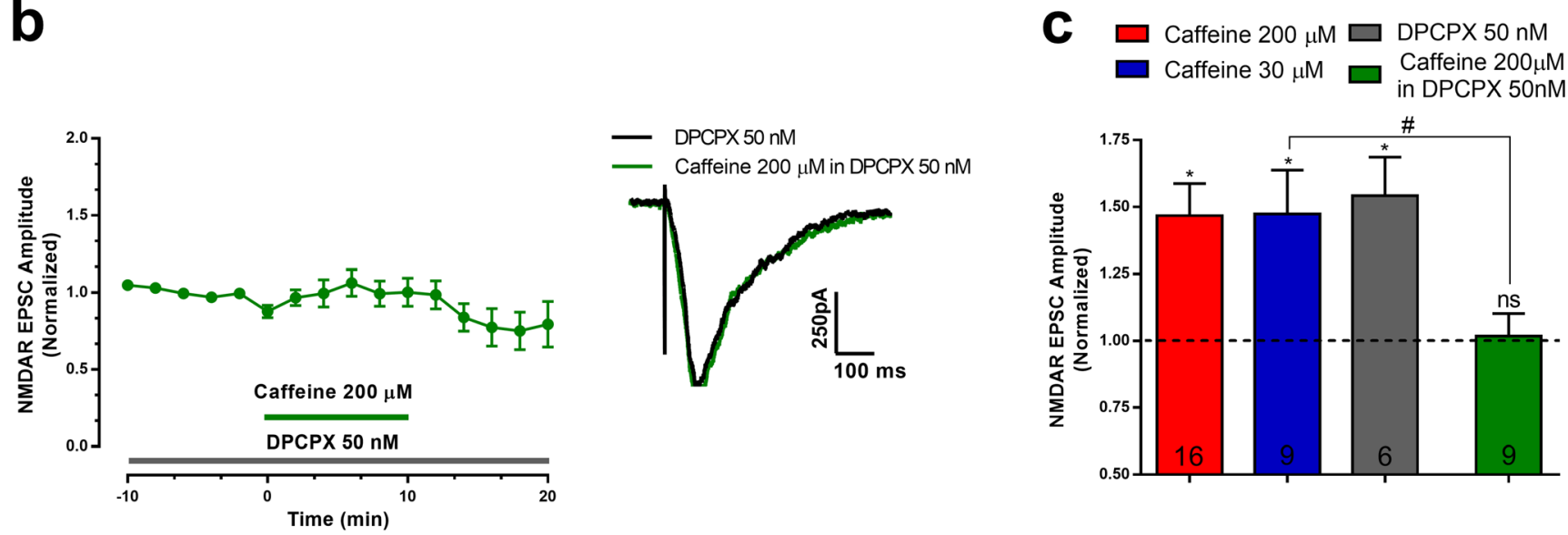

Fig. 1 Caffeine, through $\mathrm{A}_{1} \mathrm{R}$, increased the amplitude of NMDAR receptor-mediated synaptic currents. Representative trace of NMDAR currents recorded from one cell before (basal, black trace) and at $10 \mathrm{~min}$ after starting perfusion of $200 \mu \mathrm{M}$ caffeine (red trace). a Time course (left panel) and representative EPSCs (right panels) of the effect of caffeine $(30 \mu \mathrm{M}$ or $200 \mu \mathrm{M})$ or of the selective $A_{1} R$ antagonist, DPCPX $(50 \mathrm{nM})$. The horizontal bar in the left panel represents the time of drug perfusion. Each value represents the averaged amplitude of 8 consecutive responses $(2 \mathrm{~min})$. b Time course (left panel) and representative EPSCs (right panel) of the effect of caffeine $(200 \mu \mathrm{M})$ in the presence of DPCPX $(50 \mathrm{nM})$. In these experiments, DPCPX was present throughout the recordings and caffeine was added in its presence, as indicated by the horizontal line in the left panel; the representative EPSCs in the right panel are from one cell in DPCPX before (dark trace) and 15 min after adding caffeine, keeping the presence of DPCPX (green trace). c Averaged increase in current amplitude caused by the different

\section{The facilitatory action of caffeine upon NMDAR- mediated EPSCs cannot be attributed to a pre- synaptic facilitatory action upon glutamate release}

Adenosine $A_{1} R$ are known to inhibit the release of neurotransmitters, including the release of glutamate by hippocampal glutamatergic nerve terminals $[44,50,51]$. Therefore, we first hypothesized that caffeine was enhancing NMDAR-mediated EPSCs through a pre-synaptic facilitatory action that would experimental conditions shown in panels a and $\mathbf{b}$. Basal values have been normalized to 1 in each experiment, and represent the amplitude of the currents recorded for $10 \mathrm{~min}$ before addition of the test drug $(-386.3 \pm$ $95.49 \mathrm{pA}$ before caffeine $200 \mu \mathrm{M} ;-160.4 \pm 18.84 \mathrm{pA}$ before caffeine $30 \mu \mathrm{M} ;-290.6 \pm 72.05 \mathrm{pA}$ before DPCPX $50 \mathrm{nM}$ and $-396.6 \pm$ $144.8 \mathrm{pA}$ before caffeine in the presence of DPCPX $50 \mathrm{nM}$ ). Drug effect was measured by averaging responses recorded for the last 2 min of drug perfusion. Data are mean \pm S.E.M; $n$ values are indicated in each bar and represent the number of cells tested, from the same number of slices from different animals (see text for details); only one drug condition was tested in each cell and slice. $* p<0.05$ as compared with basal values; ${ }^{\#} p<0.05$ while comparing the effect of caffeine in the absence or presence of DPCPX; ns: $p>0.05$ as compared with basal values. One-way ANOVA followed by the Bonferroni post hoc test. Note that DPCPX mimicked and prevented the excitatory effect of caffeine

lead to increased availability of glutamate to activate NMDARs. To test this hypothesis, we evaluated the influence of caffeine upon paired-pulse facilitation (PPF, measured as the ratio between 2nd and 1st NMDAR-mediated EPSC amplitude, interstimulus interval of $250 \mathrm{~ms}$ ). PPF results from the transient accumulation of calcium inside the nerve terminal due to the two consecutive stimuli and reflects the synaptic release probability, so that the lower the release probability, the higher the PPF $[52,53]$. Therefore, drugs that facilitate 
a

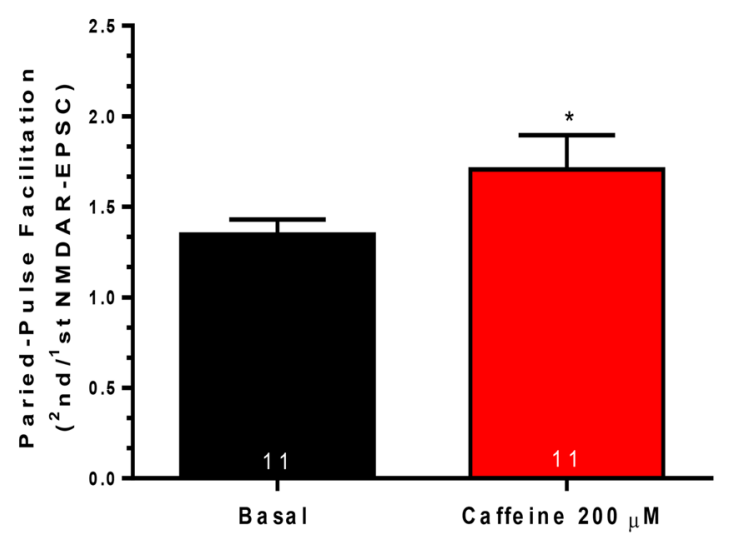

- Basa

Caffeine $200 \mu \mathrm{M}$

힝

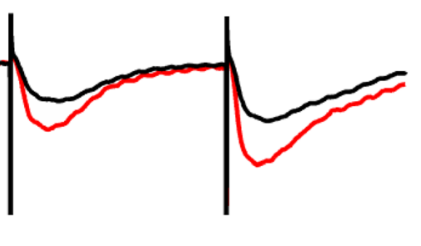

$100 \mathrm{~ms}$

b
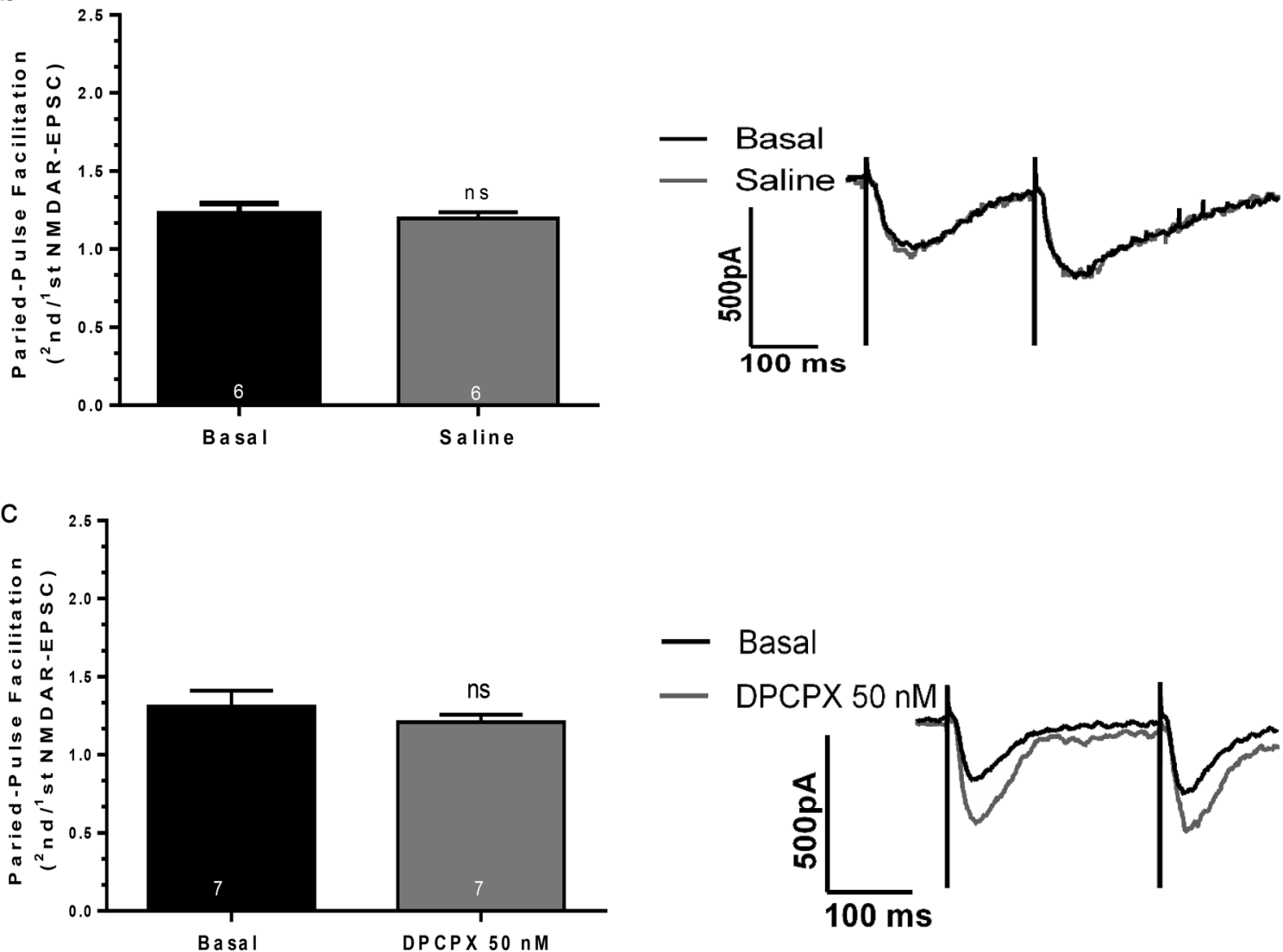

— Basal
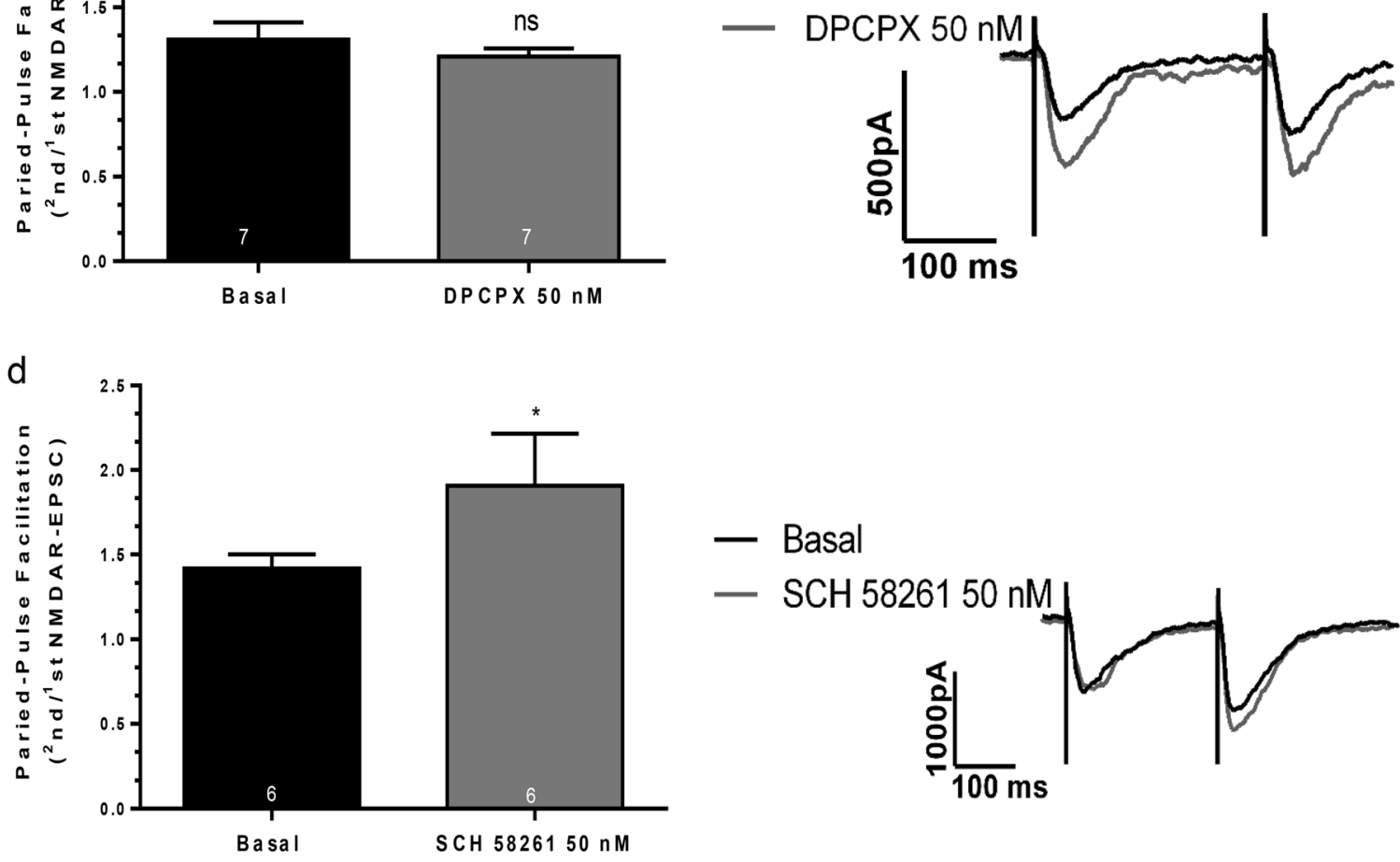

- Basal

- SCH 5826150 nM
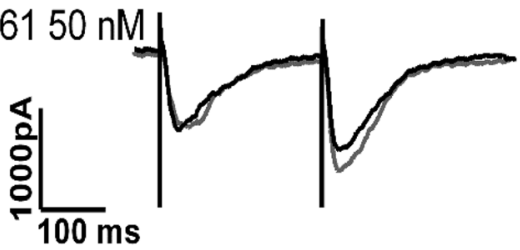
Fig. 2 Influence of caffeine $(200 \mu \mathrm{M})(\mathbf{a})$, of the $A_{1} R$ agonist, DPCPX $(50 \mathrm{nM})(\mathbf{c})$, and of the $\mathrm{A}_{2 \mathrm{~A}} \mathrm{R}$ antagonist SCH58261 (50 nM) (d) on paired-pulse facilitation (PPF) of NMDAR-mediated synaptic currents (presented as the ratio between 2nd and 1st NMDA-EPSC amplitude). In $\mathbf{b}$ are shown results from experiments where no drugs were added but the solutions were changed and time of recording kept the same as for testing drugs. PPF values (left panels) and representative current traces (right panels) before (basal) and after $10 \mathrm{~min}$ after changeover of solutions to the conditions indicated below each bar (left panels) or next to the tracings (right panels). Data are represented as mean \pm S.E.M; $n$ values are shown in each bar and indicate the number of cells tested from an equal number of slices and animals. $* p<0.05$, ns: $p>0.05$ as compared with basal values before changeover of solutions (Wilcoxon signed-rank test). Note that the $\mathrm{A}_{2 \mathrm{~A}} \mathrm{R}$ antagonist, $\mathrm{SCH} 58261$, but not DPCPX, mimicked the increase in PFF caused by caffeine

neurotransmitter release are expected to cause a decrease in PPF. Surprisingly, caffeine increased PPF of NMDARmediated EPSCs (Fig. 2a: Basal: $1.34 \pm 0.08, n=11$ cells from 11 slices from 6 mice; Caffeine: $1.70 \pm 0.19, n=11$ cells from 11 slices from 6 mice $p<0.03$ ), precluding the possibility that its facilitatory action on NMDA-mediated EPSCs would result from a facilitation of glutamate release.

\section{Blockade of pre-synaptic $A_{2 A} R$ is likely involved in a pre-synaptic inhibitory action of caffeine upon transmission}

The next series of experiments were designed to understand the nature of the increase in PPF observed in the presence of caffeine. To control for the possibility of a time-dependent run-down of neurotransmitter release leading to a timedependent increase in PPF, we performed control recordings in the absence of caffeine, keeping the recording time similar to that in the caffeine protocols. Under these control conditions, PPF was not increased (Fig. 2b: Basal: $1.22 \pm 0.06, n=$ 6 cells from 6 slices from 4 mice; $\%$ change: $1.19 \pm 0.03, n=6$ cells from 6 slices from 4 mice, $p>0.05$ ).

We then compared the action of caffeine upon PPF with that of selective $A_{1} R$ or $A_{2 A} R$ antagonists. The enhancement in PPF caused by caffeine could not be attributed to adenosine $\mathrm{A}_{1} \mathrm{R}$ blockade because it was not mimicked by DPCPX (Fig. 2c: Basal: $1.31 \pm 0.10, n=7$ cells from 7 slices from 5 mice; DPCPX: $1.20 \pm 0.04, n=7$ cells from 7 slices from 5 mice). It was, however, mimicked by SCH 58261 at a concentration $(50 \mathrm{nM})$, selective antagonist for adenosine $\mathrm{A}_{2 \mathrm{~A}} \mathrm{R}$ [54-56] (Fig. 2d, Basal: $1.42 \pm 0.08, n=6$ cells from 6 slices from 4 mice; $\mathrm{SCH} 58261: 1.90 \pm 0.30, n=6$ cells from 6 slices from 4 mice, $p<0.03)$.

Altogether, this data suggests that caffeine modulates NMDAR-mediated synaptic currents in two ways: by blocking $A_{1} R$, it likely causes a post-synaptic enhancement of transmission, and by blocking $\mathrm{A}_{2 \mathrm{~A}} \mathrm{R}$, it likely decreases availability of glutamate to activate NMDARs.

\section{Caffeine enhances neuronal intracellular $\mathrm{Ca}^{2+}$ through $A_{1} R$ blockade}

Considering the relevance of intracellular $\mathrm{Ca}^{2+}$ levels for both neurotransmitter release and for the NMDAR-mediated signaling cascade, and considering that caffeine can affect intracellular $\mathrm{Ca}^{2+}$ levels, either through adenosine receptordependent and adenosine receptor-independent ways [2, 12, 13], we tested the influence of caffeine on intracellular neuronal $\mathrm{Ca}^{2+}$ levels and assessed the role of $\mathrm{A}_{1} \mathrm{R}$ and $\mathrm{A}_{2 \mathrm{~A}} \mathrm{R}$ selective antagonists in that action. We evaluated $\mathrm{Ca}^{2+}$ signaling by the fluorescence intensity response of Fura2 after consecutive stimulation at $340 \mathrm{~nm}$ and $380 \mathrm{~nm}$, and quantified in individual cells the ratio between the two responses (F340/380, Fig. 3c). In a first set of experiments, we tested each drug individually as well as the time-dependent change in the signaling (protocol as in Fig. 3a). Recordings for 35 min after mimicking a drug change (aCSF for aCSF) did not lead to appreciable modifications in the F340/380 ratio (Fig. 3d-e). Caffeine $(200 \mu \mathrm{M})$ caused an increase $(p<0.03)$ in the basal F340/380 ratio (Fig. 3d-g) as well as increased the frequency of transient $\mathrm{Ca}^{2+}$ signaling events (Fig. 3f, j; Frequency ${ }_{\text {Basal }}$ : $0.25 \pm 0.06 \mathrm{Ca}^{2+}$ Events $/ 5 \mathrm{~min}, n=424$; Frequency ${ }_{\text {Caffeine: }}$ : $0.78 \pm 0.10 \mathrm{Ca}^{2+}$ Events $\left./ 5 \mathrm{~min}, n=18011 p<0.04\right)$. DPCPX $(50 \mathrm{nM})$ mimicked the effect of caffeine upon basal $\mathrm{Ca}^{2+}$ levels (Fig. 3d, h) as well as upon the frequency of spontaneous events (Fig. 3 h, j; Frequency ${ }_{\text {DPCPX }}$ : $0.89 \pm 0.19$ $\mathrm{Ca}^{2+}$ Events $/ 5$ min, $n=573, p<0.04$ vs basal). In contrast, SCH $58261(50 \mathrm{nM})$ did not appreciably affect either basal $\mathrm{Ca}^{2+}$ levels (Fig. 3d, k) and even decreased by near one-half the frequency of spontaneous events (Fig. $3 \mathrm{~m}$, Frequency $_{\mathrm{SCH} 58261}: 0.11 \pm 0.04 \mathrm{Ca}^{2+}$ Events $/ 5 \mathrm{~min}, n=543$ vs Frequency Basal $^{0} 0.25 \pm 0.06 \mathrm{Ca}^{2+}$ Events $/ 5 \mathrm{~min}, n=424$ ), though this effect did not prove statistically significant.

Next, we evaluated whether a pre-incubation with each of the selective adenosine receptor antagonists could blunt the action of caffeine. Upon addition of DPCPX (50 nM), an initial rise in the F340/380 ratio was detected (Fig. 3i) in agreement with the data obtained in the previous experiments (Fig. 3h). After $15 \mathrm{~min}$ in DPCPX, we added caffeine $(200 \mu \mathrm{M})$, keeping the presence of DPCPX. Under such conditions, the F340/380 ratio started to decrease back to initial levels (Fig. 3i), suggesting that caffeine has an inhibitory action upon intracellular $\mathrm{Ca}^{2+}$ levels, which can be detected when $A_{1} R$ is blocked. The frequency of signal transients was also decreased by caffeine $(200 \mu \mathrm{M})$ in the presence of DPCPX $(p<0.04$ when comparing DPCPX alone with DPCPX with caffeine), towards values (Frequency DPCPX + Caffeine: $0.16 \pm 0.04 \mathrm{Ca}^{2+}$ Events $/ 5 \mathrm{~min}, n=283$ ) even slightly lower than those detected before addition of any drug (Fig. 3j). 


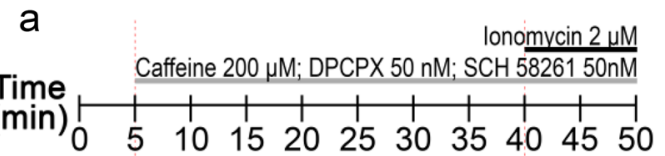
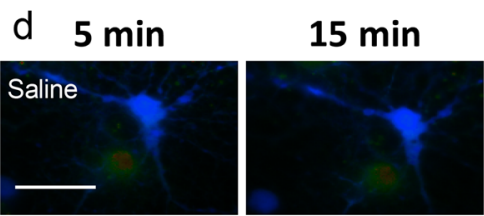

$30 \mathrm{~min} 45 \mathrm{~min}$ : lonomycin

b

lonomycin $2 \mu \mathrm{M}$ Caffeine $200 \mu \mathrm{M}$
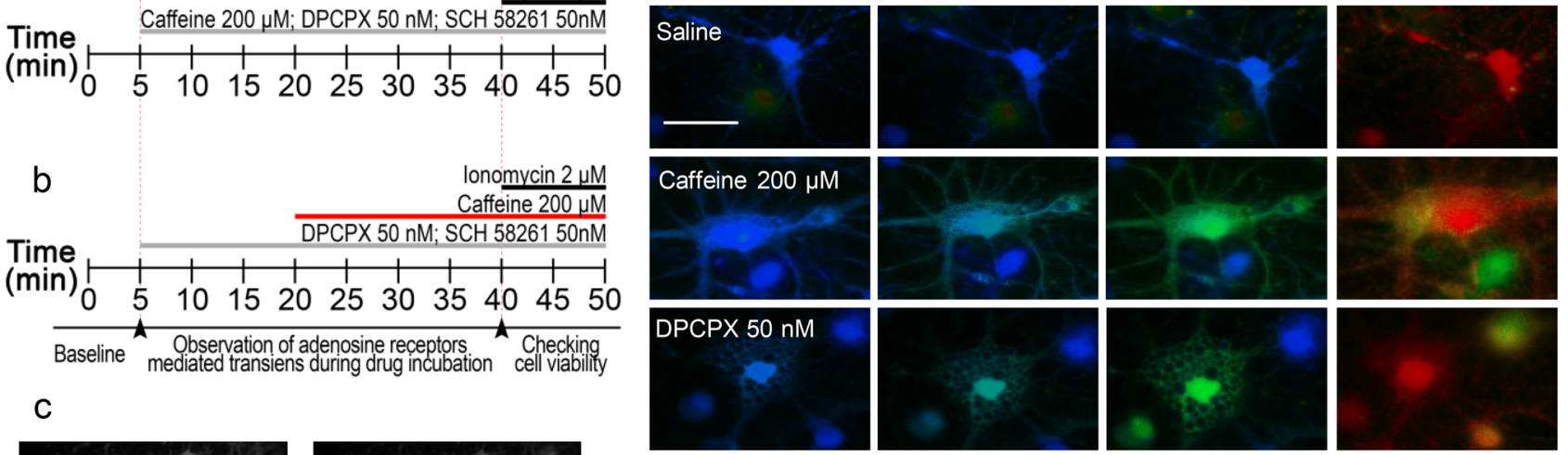

C
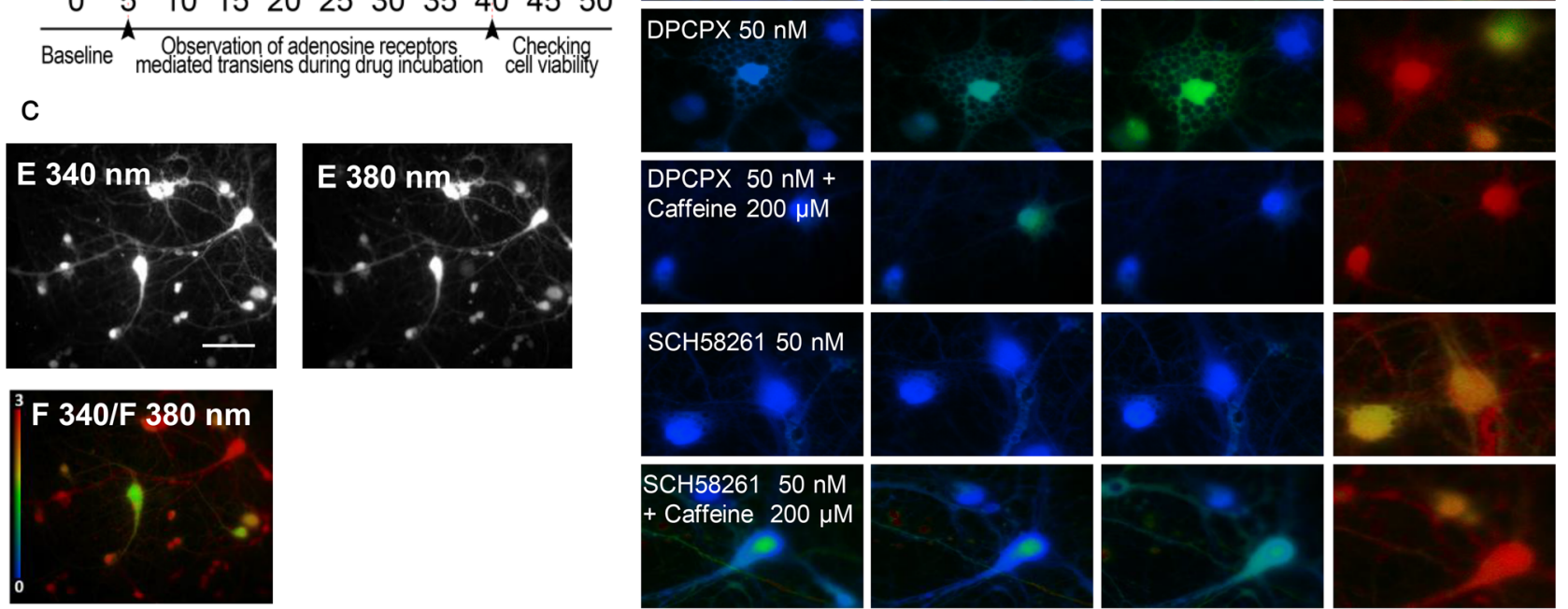

SCH58261 $50 \mathrm{nM}$
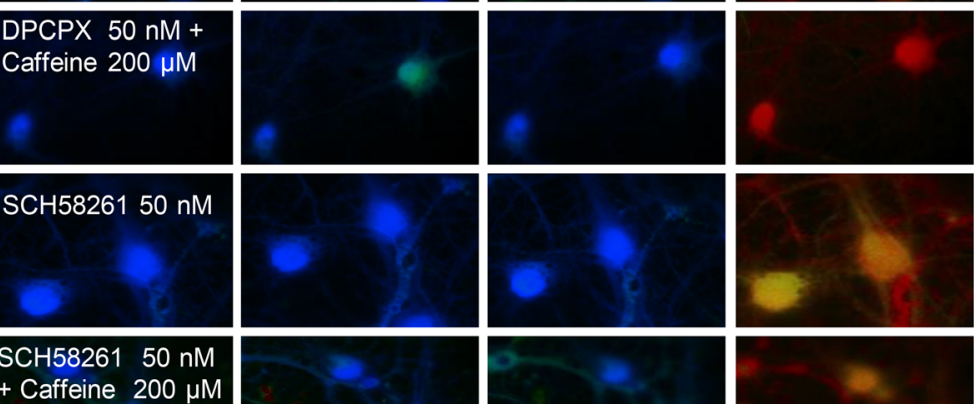

+ Caffeine $200 \mu \mathrm{M}$
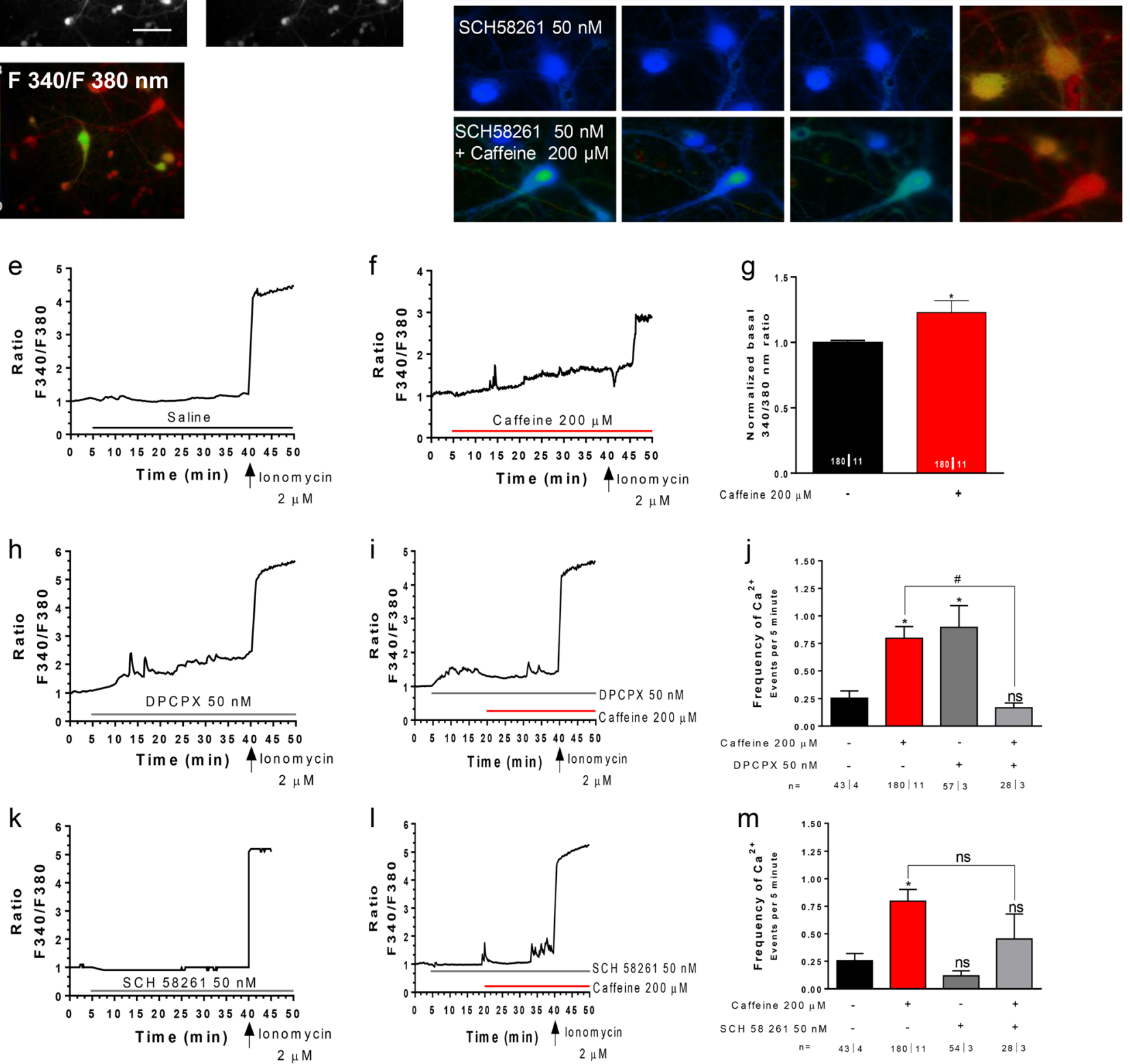
Fig. 3 Caffeine exposure increases intracellular $\mathrm{Ca}^{2+}$ levels and the frequency of $\mathrm{Ca}^{2+}$ transients in neuron cell culture. a, b Time lines representing the order and timing for each drug administration. $\mathbf{c} \mathrm{Ca}^{2+}$ imaging and representative images of relative fluorescence in 340 and $380 \mathrm{~nm}$. d Representative images of neurons kept all time in saline (first row) or to be challenged (immediately after min 5) with caffeine $(200 \mu \mathrm{M})$, DPCPX $(50 \mathrm{nM})$, and $\mathrm{SCH} 5861(50 \mathrm{nM})$, as indicated in the left panel of each row; the recording times are indicated in the top panel of each column; the last column shows the response to the $\mathrm{Ca}^{2+}$ ionophore ionomycin $(2 \mu \mathrm{M})$, to access maximum $\mathrm{Ca}^{2+}$ increase, thus an indirect way of accessing cell viability before ionomycin; min 5 (first column) shows responses immediately before addition of drugs. The time course panels show representative tracings (one tracing per cell) of the changes of the ratio between responses to F340 and F380 nanometer wavelength (F340/F380) during exposure to saline (e), caffeine (f), DPCPX (h), caffeine in the presence of DPCPX (i), SCH $58261(\mathrm{k})$, caffeine in the presence of SCH 58261 (1), as indicated by the horizontal bars; in each cell, the tracings have been normalized, so that the first ratio of the first recording was taken as 1 . Panel $\mathbf{g}$ illustrates the averaged $\mathrm{F} 340 / \mathrm{F} 380$ ratio recorded at $0-5 \mathrm{~min}$ in the absence of caffeine and at $40-45 \mathrm{~min}$ in the presence of caffeine, as indicated below the bars. Panels $\mathbf{j}$ and $\mathbf{m}$ show averaged frequency of $\mathrm{Ca}^{2+}$ transients recorded during exposure to the drug conditions indicated below each bar. Values in similar drug conditions in $\mathbf{j}$ and $\mathbf{m}$ are from the same cells and are repeated to allow comparisons. Data in $\mathbf{g}$, $\mathbf{j}$, and $\mathbf{m}$ are represented as mean \pm S.E.M; $n$ values are indicated below each bar and correspond to the number of cells/taken from the identified number of independent cultures. $* p<0.05$; ns: $p>0.05$ as compared with control values in saline; ${ }^{\#} p<0.05$ as compared with values with caffeine in the absence of the selective adenosine receptor antagonists (Mann-Whitney test in $\mathbf{g}$; twoway ANOVA followed by Bonferroni post hoc test in $\mathbf{j}$ and $\mathbf{m}$ ). Scale bar in $\mathbf{c}: 20 \mu \mathrm{m}$ and $\mathbf{d}: 10 \mu \mathrm{m}$, and applies to all images in the same panel

Considering that inhibitory action of caffeine in the presence of DPCPX had similarities with the effect of the selective $\mathrm{A}_{2 \mathrm{~A}} \mathrm{R}$ antagonist, SCH 58261 (50 nM), when applied alone, we hypothesized that it could result from blockade of $\mathrm{A}_{2 \mathrm{~A}} \mathrm{R}$. If so, the effect should be blunted by the presence of SCH 58261. It was indeed the case, as can be concluded from the data in Fig. $3 \mathrm{~m}$. When caffeine $(200 \mu \mathrm{M})$ was applied in the presence of $\mathrm{SCH}$ 58261 , it not only did not inhibit the frequency of $\mathrm{Ca}^{2+}$ signals, but even tended to increase the frequency towards a value

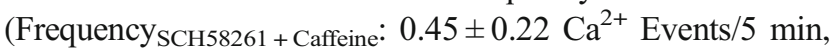
$n=283$ ) intermediate from that observed with caffeine alone and in absence of any drugs (Fig.31, m).

We then tested the effect of a lower concentration of caffeine $(30 \mu \mathrm{M})$ to mitigate its adenosine receptor-independent action upon mobilization of intracellular $\mathrm{Ca}^{2+}$ stores. We confirmed that even at this lower and submaximal concentration, caffeine could promote an increase in the frequency of $\mathrm{Ca}^{2+}$ transients (Fig. 4a-c: Frequency ${ }_{\text {Basal }}: 0.29 \pm 0.07 \mathrm{Ca}^{2+}$ Events/ $5 \mathrm{~min}, n=434$; Frequency ${ }_{\text {Caffeine }} 30 \mu \mathrm{M}: 0.61 \pm 0.08 \mathrm{Ca}^{2+}$ Events $/ 5 \min , n=482, p<0.009)$, though being virtually devoid of effect in basal $\mathrm{Ca}^{2+}$ levels.

Altogether, these results suggest that caffeine can act at least in two opposite ways to control intracellular $\mathrm{Ca}^{2+}$ levels in neurons: (1) through blockade of $\mathrm{A}_{1} \mathrm{R}$ leading to increases in basal $\mathrm{Ca}^{2+}$ levels as well as to increases in $\mathrm{Ca}^{2+}$ transients;
(2) through blockade of $\mathrm{A}_{2 \mathrm{~A}} \mathrm{R}$ leading to decreases in intracellular $\mathrm{Ca}^{2+}$, an action only evident when $\mathrm{A}_{1} \mathrm{R}$ is blocked, indicating that the predominant action of caffeine is a result of $\mathrm{A}_{1} \mathrm{R}$ blockade.

\section{NMDAR is involved in the facilitatory action of caffeine upon intracellular $\mathrm{Ca}^{2+}$ levels}

It is well known that NMDAR is permeable to $\mathrm{Ca}^{2+}[57]$. We therefore assessed whether the $\mathrm{A}_{1} \mathrm{R}$-mediated facilitatory action of caffeine upon NMDAR could be related to the facilitatory action of this xanthine upon intracellular $\mathrm{Ca}^{2+}$ levels. To test this possibility, we evaluated the effect of caffeine upon $\mathrm{Ca}^{2+}$ signaling in neurons in presence of a NMDAR blocker, DL-2-amino-5-phosphonopentanoic acid (AP5). When applied alone, AP5 $(50 \mu \mathrm{M})$ was virtually devoid of effect upon basal F340/380 ratio (Fig. 5b) as well as upon the frequency of the signal transients (Fig. 5d, Frequency ${ }_{\text {Basal }}$ : $0.29 \pm 0.07$ $\mathrm{Ca}^{2+}$ Events/5 $\min , n=43$ 4; Frequency ${ }_{\mathrm{AP} 5}: 0.18 \pm 0.04$ $\mathrm{Ca}^{2+}$ Events/5 min, $\left.n=794\right)$. Importantly, caffeine applied in the presence of AP5 could no longer increase either the basal $\mathrm{Ca}^{2+}$ levels (Fig. 5a-d) or the frequency of the transients (Fig. $5 \mathrm{~d}$, Frequency ${ }_{\mathrm{AP} 5}+$ Caffeine: $0.23 \pm 0.06 \mathrm{Ca}^{2+}$ Events $/ 5 \mathrm{~min}, n=$ $404)$. As expected, the effect of caffeine alone was significantly different $(p<0.007)$ from that of caffeine in the presence of AP5 (Fig. 5d). Altogether, these data show that $\mathrm{Ca}^{2+}$ entry through NMDAR contributes to the facilitatory action of caffeine upon intracellular neuronal $\mathrm{Ca}^{2+}$ signaling.

\section{Discussion}

We herein describe for the first time that acute caffeine in micromolar concentrations facilitates NMDAR-mediated synaptic currents and $\mathrm{Ca}^{2+}$ signaling on hippocampal neurons and that this effect results from $A_{1} R$ blockade. The facilitation of synaptic currents could not be attributed to an increase in the pre-synaptic release of glutamate. Conversely, caffeine seems to cause a decrease in glutamate release, an action mimicked by an $\mathrm{A}_{2 \mathrm{~A}} \mathrm{R}$ antagonist suggesting that it may result from $\mathrm{A}_{2 \mathrm{~A}} \mathrm{R}$ blockade. The net effect of caffeine on synaptic NMDAR-mediated currents is, however, a facilitatory one, indicating that under the conditions used, the $\mathrm{A}_{1} \mathrm{R}$-mediated actions prevail over the $\mathrm{A}_{2 \mathrm{~A}} \mathrm{R}$-mediated ones, which is not surprising on the light of the relative distribution of the two high-affinity receptors at the hippocampus $[17,18]$. Concerning the effect of caffeine on $\mathrm{Ca}^{2+}$ transients in neurons, we also observed a facilitation mediated by $\mathrm{A}_{1} \mathrm{R}$ blockade. The caffeine-induced enhancement of $\mathrm{Ca}^{2+}$ transients clearly involved activation of NMDAR, since it was fully prevented in the presence of a NMDAR antagonist. This highlights an inhibitory action of $\mathrm{A}_{1} \mathrm{R}$ upon $\mathrm{Ca}^{2+}$ entry 
a

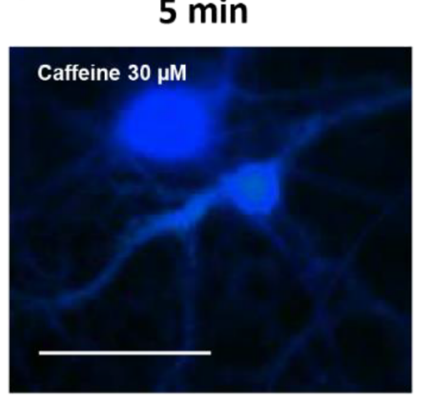

$15 \mathrm{~min}$

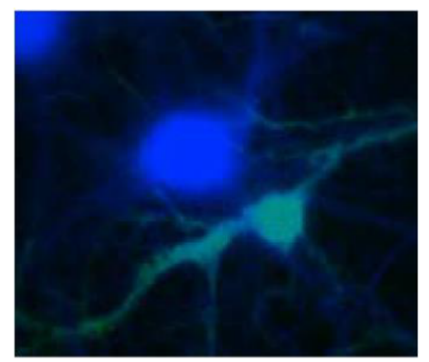

Fig. 4 At a lower concentration $(30 \mu \mathrm{M})$, caffeine also increases the frequency of $\mathrm{Ca}^{2+}$ transients in neurons. a Representative images of neurons taken immediately before adding caffeine (left image); caffeine was added at $5 \mathrm{~min}$; the images displayed were taken at the times indicated above each recording; the last image shows the response to the $\mathrm{Ca}^{2+}$ ionophore ionomycin $(2 \mu \mathrm{M})$, to access maximum $\mathrm{Ca}^{2+}$ increase, thus an indirect way of accessing cell viability before ionomycin. b Representative tracing of time-course changes of the ratio between responses to F340 and F380 nanometer wavelength during

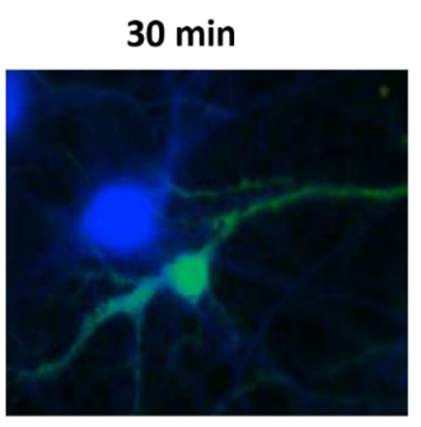

\section{5 min: Ionomycin}
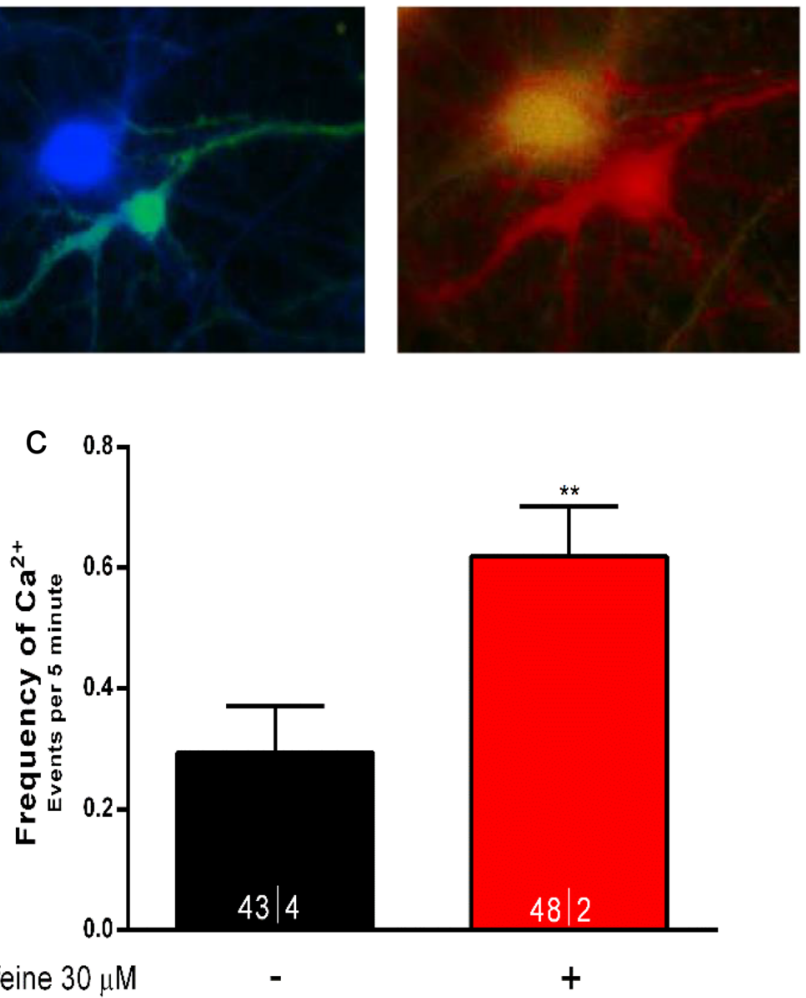

Caffeine $30 \mu \mathrm{M}$

exposure of one of the cells to caffeine; the tracing has been normalized so that the first ratio of the first recording was taken as 1 . Panel $\mathbf{c}$ shows averaged frequency of $\mathrm{Ca}^{2+}$ transients recorded during caffeine perfusion; data are represented as mean \pm S.E.M; $n$ values are indicated below each bar and correspond to the number of cells/taken from the identified number of independent cultures. $* * p<0.01$ as compared with control values in saline (Wilcoxon signed-rank test in c). Note caffeine $30 \mu \mathrm{M}$, mimicked effect of caffeine $200 \mu \mathrm{M}$ on the frequency of $\mathrm{Ca}^{2+}$ transients. Scale bar in $\mathbf{a}: 10 \mu \mathrm{m}$, and applies to all images through NMDAR in hippocampal neurons. Interestingly, when the $A_{1} R$ was blocked, caffeine slightly decreased $\mathrm{Ca}^{2+}$ signals, an effect mimicked by an $\mathrm{A}_{2 \mathrm{~A}} \mathrm{R}$ antagonist. Again, the facilitation by caffeine prevails upon the inhibitory action when both high-affinity adenosine receptors were available to be blocked.

On the light of the known actions of adenosine receptors upon hippocampal synaptic transmission, the relative distribution of $A_{1} R$ and $A_{2 A} R$ in hippocampal neurons, their predominance in pre-synaptic vs post-synaptic sites at hippocampal synapses $[23,58]$, as well on the similar affinity of caffeine for $A_{1} R$ and $A_{2 A} R[12,59]$, one would expect that most of the actions of caffeine upon glutamatergic transmission would be to canceal the pre-synaptic inhibitory action of $A_{1} R$ upon glutamate release. This has been the canonic interpretation for the facilitatory actions of caffeine upon hippocampal synaptic transmission $[28,56,60]$, long-term potentiation [28], and induction of a non-NMDA form of synaptic plasticity [61].

Due to the relevance of NMDARs not only for synaptic platicity, cognition, memory, learning [31, 32], synapse formation, remodeling, elimination [62], neuronal migration [63], proliferation, and differentiation [64], but also for excitotoxicity [65], we focused on the possibility that caffeine could modulate the NMDAR-mediated component of glutamatergic transmission. Our data showing that caffeine ehances the NMDAR-mediated component of synaptic currents, through a mechanism that could not be related to pre-synaptic facilitation of neurotransmitter release, suggests that endogenous adenosine is tonically inhibiting NMDARs. Since this action was mimicked by DPCPX and occluded by prior application of DPCPX, the adenosine receptor involved in this tonic modulation might belong to the $A_{1} R$ subtype. This conclusion agrees with 
previous reports that post-synaptic very high-affinity adenosine $A_{1}$ Rs inhibit NMDA currents in dissociated hipocampal neurons [33] and highlights a role for endogenous adenosine as modulator of NMDAR function. Importantly also, we could show that it impacts in NMDAR-mediated $\mathrm{Ca}^{2+}$ oscillations in neurons. Glutamatergic synaptic maturation is highly dependent of synaptic NMDAR activation and $\mathrm{Ca}^{2+}$ oscillations at critical time points during development [66]. Thus, proper adjustment of endogenous modulation of NMDARs might be required for appropriate synaptic maturation. Caffeine exposure during gestation has been shown to affect maturation of GABAergic neurons, an action likely mediated by both $A_{1} R$ [67] and $A_{2 A} R$ [68]. The present study showing that caffeine modulates synaptic responses and $\mathrm{Ca}^{2+}$ oscillations mediated by NMDARs points towards the possibility that exposure to caffeine during critical developmental periods may also affect fine tuning of glutamatergic circuits, a possibility clearly deserving future research.

The adenosine $A_{1} R$-mediated protection against excitotoxicity has been mostly associated to its ability to inhibit glutamate release, whereas $\mathrm{A}_{2 \mathrm{~A}} \mathrm{R}$ activation leads to excitotoxicity exacerbation $[20,44,45]$ and so, neuroprotective actions of caffeine are usually a consequence of $\mathrm{A}_{2 \mathrm{~A}} \mathrm{R}$ blockade. Since there is plenty of evidence on the neuroprotective actions of caffeine to delay neurodegenerative disease progression, caffeine is frequently referred as having predominant $\mathrm{A}_{2 \mathrm{~A}} \mathrm{R}$ antagonistic properties. This might be so in brain areas, as the basal ganglia, where $\mathrm{A}_{2 \mathrm{~A}} \mathrm{R}$ predominate, or in situations where $\mathrm{A}_{2 \mathrm{~A}} \mathrm{R}$ activity gains particular relevance, as in neurodegeneration or aging, where there is an upregulation of $A_{2 A} R$ [69]. But we now used young animals and as we show, at this age, $A_{1} R$ antagonism by caffeine prevails over $\mathrm{A}_{2 \mathrm{~A}} \mathrm{R}$ antagonism to influence NMDAR at the hippocampus.

Evidence that tonic activation by $\mathrm{A}_{1} \mathrm{R}$ can protect neurons by decreasing NMDAR overactivation under hypoxic conditions has already been published and has been interpreted as a consequence of inhibition of neurotransmitter release [41]. The present work adds a further piece to the puzzling role of neuroprotection by adenosine by showing for the first time results compatible with the conclusion that tonic $A_{1} R$ activation by endogenous adenosine inhibits NMDAR-mediated responses in hippocampal neurons. As we also show, this inhibition impacts on $\mathrm{Ca}^{2+}$ homeosthasis, therefore, has a putative protective influence upon excitotoxicity, independently of the A1Rmediated ability to inhibit glutamate release.

Somehow surprising was the influence of the selective $\mathrm{A}_{2 \mathrm{~A}} \mathrm{R}$ antagonist upon paired pulse facilitation of NMDAR-mediated EPSCs, an action mimicked by caffeine and compatible with a tonic facilitatory action of $A_{2 A} R$ upon glutamate release. The selective $A_{1} R$ antagonist was devoid of effect upon PPF. This could result from the absence of pre-synaptic $A_{1} R$ activation on glutamatergic nerve terminals, which is highly unlikely, considering the well-known influence of $A_{1} R$ to presynaptically inhibit glutamate release at the hippocampus [50, 51, 70]. Indeed, while mostly assessing AMPA receptor-mediated synaptic transmission through field excitatory synaptic potential recordings, it has been observed that DPCPX [71, 72], as well as caffeine due to presynaptic $A_{1} R$ blockade [30], inhibit PPF. Alternatively, our data may indicate that the levels of endogenous adenosine in our experimental conditions are not enough to activate pre-synaptic inhibitory $A_{1} R$, though being enough to activate the $A_{1} R$ inhibitory post-synaptic receptors that reduce NMDAR function. This possibility agrees with reports that effective concentrations of adenosine are at least one order of magnitude lower to inhibit NMDAR-mediated currents [33] than to inhibit synaptic fast excitatory synaptic transmission at the hippocampus [50,51]. If so, one has to assume either that (1) pre-synaptic inhibitory $\mathrm{A}_{1} \mathrm{R}$ receptors have lower affinity for adenosine and/or lower efficacy to control release than pre-synaptic $\mathrm{A}_{2 \mathrm{~A}} \mathrm{R}$, or that (2) a facilitation of glutamate release due to pre-synaptic $A_{1} R$ blockade does not affect NMDAR-mediated responses, whereas an inhibition of glutamate release due to blockade of $\mathrm{A}_{2 \mathrm{~A}} \mathrm{R}$-mediated facilitation does. Though we cannot preclude the first possibility (affinity/efficacy differences), the second one seems likely. Thus, to activate synaptic NMDAR, there is a need of strong pre-synaptic stimulation and therefore the consequences of a further facilitation of glutamate release may be more difficult to detect than the consequences of inhibition of glutamate release. NMDAR activation may lead to further activation of NMDARmediated responses [73] and this could hamper the increase in EPSC caused by the second stimulus when the release is facilitated by $A_{1} R$ blockade. This ceiling effect is likely mitigated when release probability is lowered due to blockade of $\mathrm{A}_{2 \mathrm{~A}} \mathrm{R}$-mediated facilitation. We can also argue that paired-pulse facilitation of NMDAR-mediated currents encompasses a post-synaptic component besides a pre-synaptic one [74], and therefore the alterations of PPF caused by the $A_{2 A} R$ antagonist and caffeine should not be interpreted only on the basis of a decrease of neurotransmitter release due to blockade of pre-synaptic $\mathrm{A}_{2 \mathrm{~A}}$ Rs. Indeed, $\mathrm{A}_{2 \mathrm{~A}} \mathrm{R}$ activation can post-synaptically facilitate NMDAR-mediated currents at the hippocampus [24] and can trigger a NMDAR-dependent form of LTP in hippocampal areas where plasticity is mostly nonNMDAR dependent [35]. $A_{2 A} R$ are also known to facilitate synaptic plasticity phenomena both ex vivo [30] and in vivo [75]. How these $A_{2 A} R$-mediated actions would affect a putative post-synaptic component of the NMDA PPF is difficult to predict. 
a

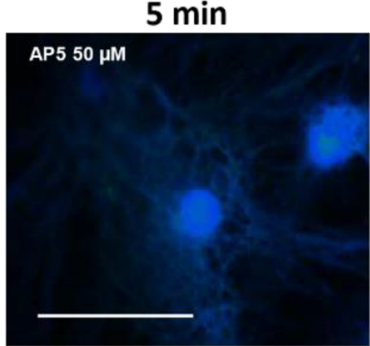

AP5 $50 \mu \mathrm{M}+$ Caffeine $200 \mu \mathrm{M}$
$15 \mathrm{~min}$
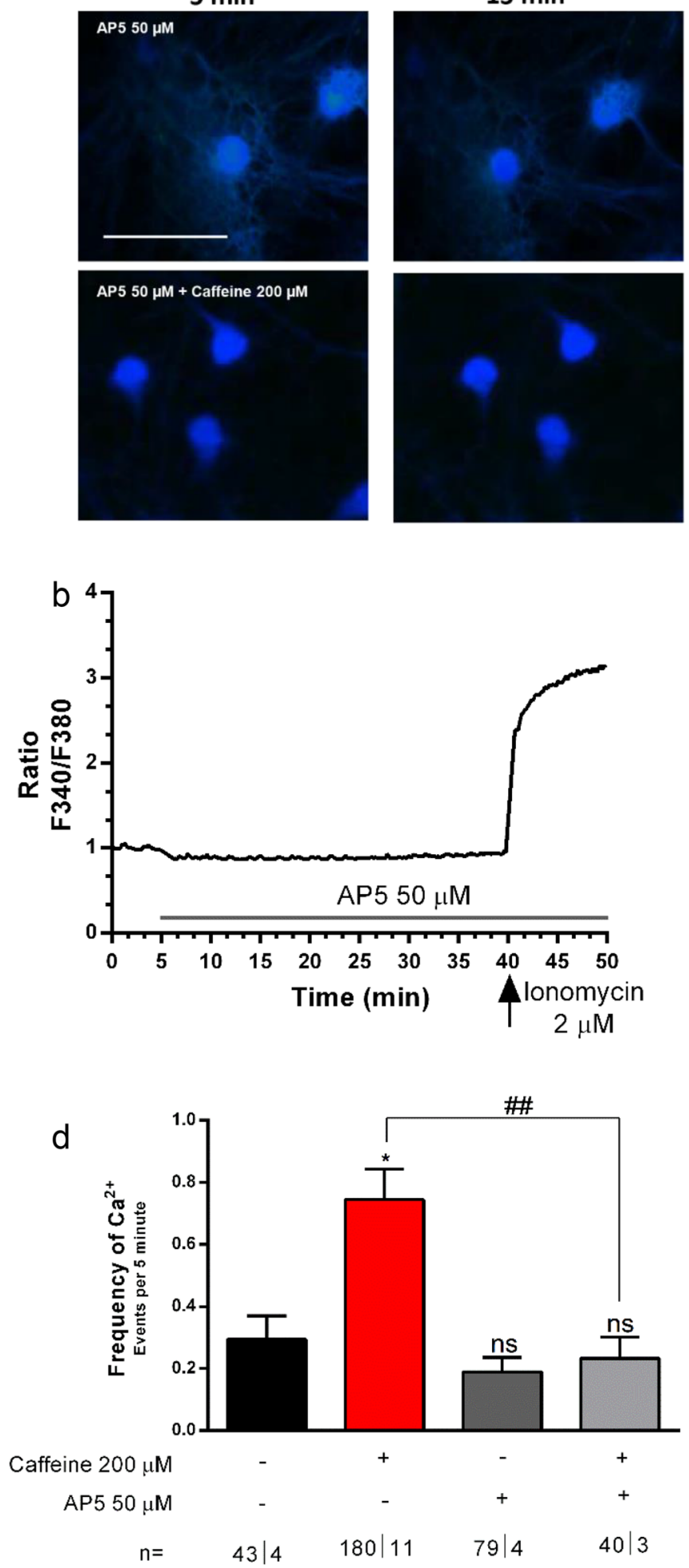

A biphasic effect of caffeine to control the release of acetylcholine has been reported [76] and tentatively interpreted as resulting from antagonism of $A_{1}$ and $A_{2}$

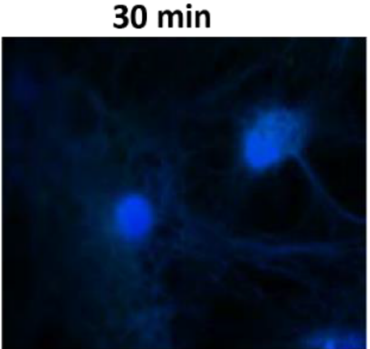

\section{5 min: Ionomycin}
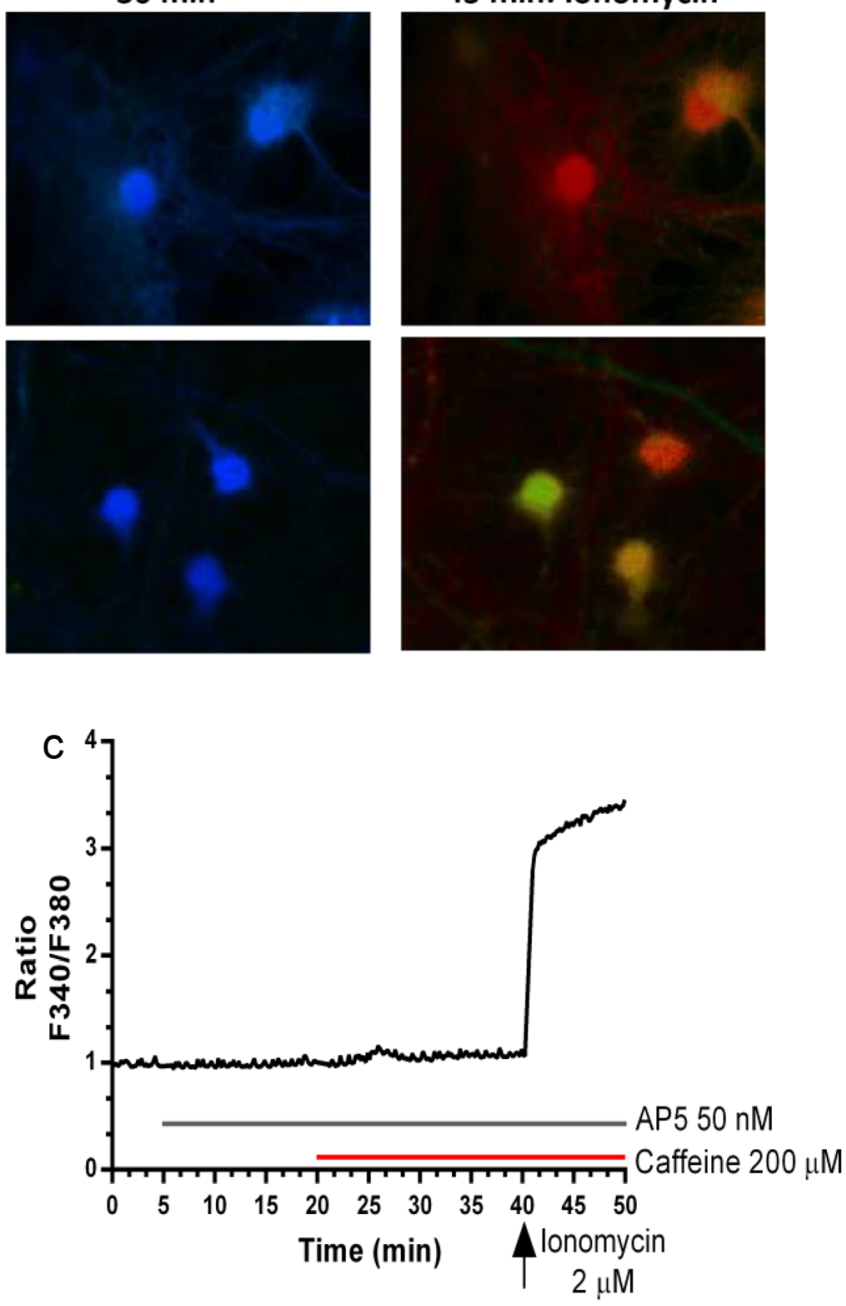

receptors known to control acetylcholine release in the cortex [77]. However, different concentrations of caffeine were required to observe the facilitatory and the inhibitory 
Fig. 5 The increase in intracellular $\mathrm{Ca}^{2+}$ levels and induction of $\mathrm{Ca}^{2+}$ transients caused by caffeine $(200 \mu \mathrm{M})$ is mediated by NMDAR. a Representative images of neurons taken at the times indicated on the top of the images; the first row shows images taken from neurons where only the effect of the NMDAR antagonist, AP5 $(50 \mu \mathrm{M})$, was tested; the second row shows images from neurons where the effect of caffeine in the presence of AP5 was tested; the first image in each row was taken immediately before adding any drug $(5 \mathrm{~min})$ and the last image in each row represents the response to the $\mathrm{Ca}^{2+}$ ionophore, ionomycin $(2 \mu \mathrm{M})$, added to access maximum $\mathrm{Ca}^{2+}$ increase, thus an indirect way of accessing cell viability before ionomycin; in both rows, the neurons were exposed from 5 min onwards to AP5 $(50 \mu \mathrm{M})$; in the lower row, the neurons were then further exposed to caffeine $(200 \mu \mathrm{M})$, which was added at $20 \mathrm{~min}$, therefore between the 2nd and 3rd image. Panels $\mathbf{b}$ and $\mathbf{c}$ show representative tracings (one tracing per cell) of the time-course changes of the ratio between responses to F340 and F380 nanometer wavelength during exposure to AP5 only (b), or caffeine in the presence of AP5 (c), which were added at the times indicated by the horizontal bars; in each cell, the tracings have been normalized so that the first ratio of the first recording was taken as 1 . Panel $\mathbf{d}$ shows averaged frequency of $\mathrm{Ca}^{2+}$ transients recorded in the drug conditions indicated below each bar; values under similar drug conditions than those in Fig. $4 \mathrm{j}$ and $\mathrm{m}$ are the same and are repeated here to allow comparisons; data are represented as mean \pm S.E.M; $n$ values are indicated below each bar and correspond to number of cells/taken from the identified number of independent cultures. $* p<0.05$; ns: $p>0.05$ as compared with control values in saline; ${ }^{\# \#} p<0.01$ as compared with values with caffeine in the absence of the selective NMDAR antagonists (Two-way ANOVA followed by the Bonferroni post hoc test in $\mathbf{d}$. Scale bar in a: $10 \mu \mathrm{m}$, and applies to all images effect. We herein show that caffeine can exert this dual role at the same concentration, allowing the suggestion that the relative influence of caffeine likely depends on the relative contribution of the high-affinity adenosine receptors $\left(A_{1} R\right.$ and $\left.A_{2 A} R\right)$ to control a specific brain function. Importantly, we report a dual role of caffeine as modulator of the activity of a receptor, the NMDA receptor, that by itself has dual functions in the brain.

In conclusion, our data suggest that acute caffeine exposure of hippocampal neurons of adolescent mice has dual and opposing effects on the NMDA component of glutamatergic synaptic transmission. The predominant action is exerted at the post-synaptic level to enhance NMDAR activity via blockade of inhibitory $A_{1} R$, with a consequent increase of $\mathrm{Ca}^{2+}$ levels. By blocking facilitatory $\mathrm{A}_{2 \mathrm{~A}} \mathrm{R}$ likely located pre-synaptically, caffeine leads to a decrease in glutamate release probability, a mechanism that may at least in part counteract the excitatory action upon NMDAR-mediated transmission (Fig. 7). These results, showing that relatively low concentrations of caffeine acting upon adenosine receptors can influence NMDAR activity and perturb $\mathrm{Ca}^{2+}$ oscillations at the hippocampus, highlight the need to further investigate how early exposure to caffeine during gestational periods or during adolescence affects neuronal differentiation and synaptic maturation, known to be highly dependent of properly adjusted $\mathrm{Ca}^{2+}$ homeostasis.
Fig. 6 Schematization of caffeine action on its adenosine receptors targets and their impact in

NMDAR-mediated responses. At the post-synaptic level caffeine acts via $\mathrm{A}_{1} \mathrm{R}$ blockade, affecting $\mathrm{Ca}^{2+}$ homeostasis by promoting an increase in $\mathrm{Ca}^{2+}$ entry through NMDAR. At the pre-synaptic level, caffeine, by blocking $\mathrm{A}_{2 \mathrm{~A}} \mathrm{R}$, decreases glutamate release, which may counteract the excitatory action and, in such way, contribute to maintaining synaptic transmission homeostasis.

Changes in the relative contribution to these two opposing actions throughout life as well as under different pathologies may lead to different global actions of caffeine on NMDAR-mediated responses

\section{Presynaptic neuron}

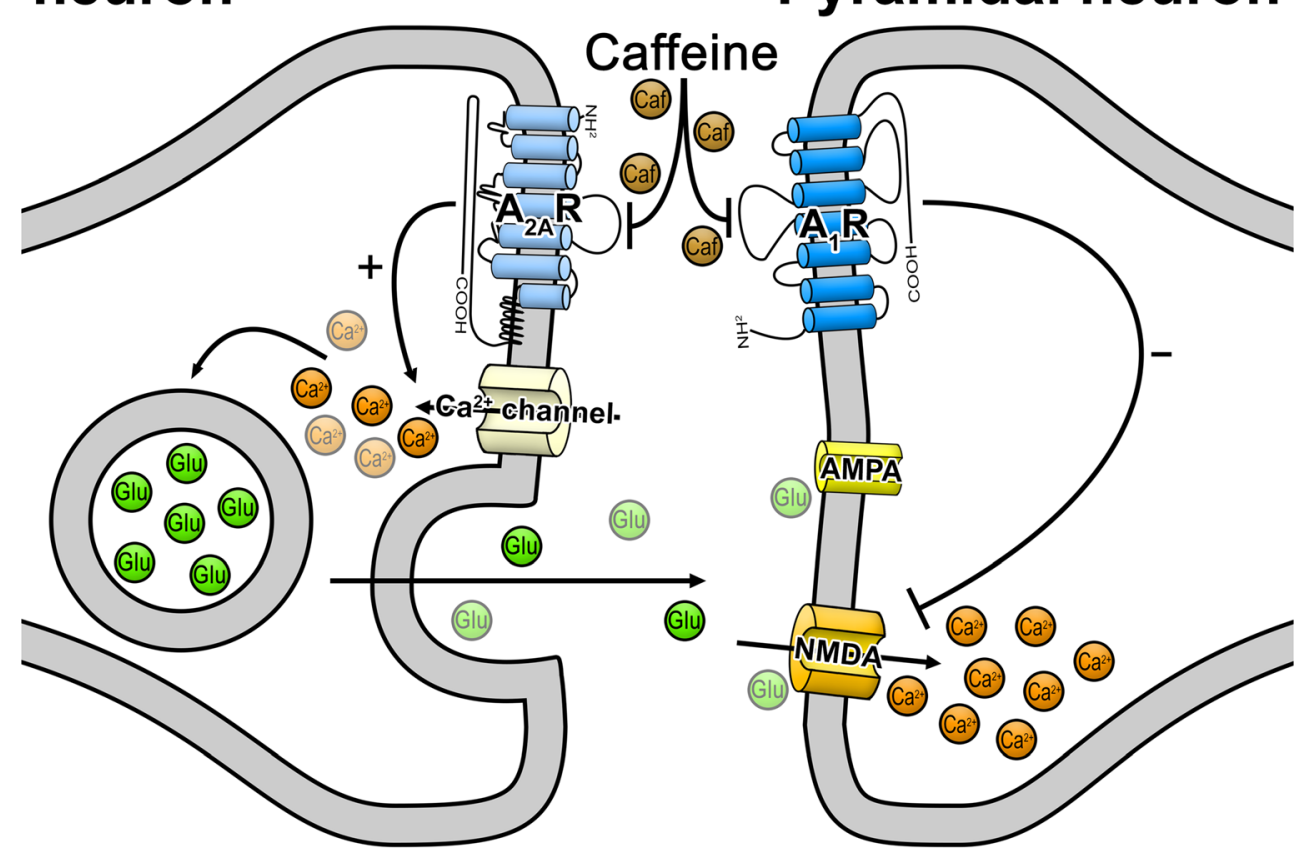


Acknowledgments The authors in Portugal are members of an EU twinning action (Project grant 952455). While revising this work, the authors want to make a special tribute to Geoffrey Burnstock for his great contributions to science, for defending and enlarging the knowledge of the purinergic field to the very end of his life, for his friendship and trust even in very difficult circumstances, which will never be forgotten. Thanks Geoff. Your legacy will last forever. We will miss your loud voice and laugh.

\section{Code availability Not applicable}

Funding Robertta Silva Martins was in receipt of a fellowship from Fundação de Amparo à Pesquisa do Estado do Rio de Jan eiroFAPERJ, Brasil, Bolsa de Doutorado Sanduíche Europa/Oriente (grant number E-26/201.599/2018). The work was supported by Fundação para a Ciência e Tecnologia, Portugal (project grant PTDC/MED-FAR/30933/ 2017).

Data availability Not applicable

\section{Compliance with ethical standards}

Conflicts of interest The authors declare that they have no conflict of interest.

Ethics approval All experimental procedures were performed according to European Community Guidelines (Directive 2010/63/EU) and the Portuguese Law (DL 113/2013) for animal care for research purposes and were approved by the "Instituto de Medicina Molecular" Internal Committee and the Portuguese Animal Ethics Committee - Direcção Geral de Veterinária.

Consent to participate Not applicable

Consent for publication Not applicable

\section{References}

1. Meeusen R, Roelands B, Spriet LL (2013) Caffeine, exercise and the brain. Nestle Nutr Inst work Ser 76:1-12. https://doi.org/10. $1159 / 000350223$

2. Cappelletti S, Piacentino D, Sani G, Aromatario M (2015) Caffeine: cognitive and physical performance enhancer or psychoactive drug? Curr Neuropharmacol 13:71-88. /https://doi.org/10.2174/ 1570159X13666141210215655

3. Hackett PH (2010) Caffeine at high altitude: java at base cAMP. High alt med biol 11:13-17. https://doi.org/10.1089/ham.2009. 1077

4. Mitchell DC, Hockenberry J, Teplansky R, Hartman TJ (2015) Assessing dietary exposure to caffeine from beverages in the U.S. population using brand-specific versus category-specific caffeine values. Food Chem Toxicol 80:247-252. https://doi.org/10.1016/ j.fct.2015.03.024

5. Poole RL, Braak D, Gould TJ (2016) Concentration- and agedependent effects of chronic caffeine on contextual fear conditioning in C57BL/6J mice. Behav brain res 298:69-77. https://doi.org/ 10.1016/j.bbr.2015.03.045

6. Wikoff D, Welsh BT, Henderson R et al (2017) Systematic review of the potential adverse effects of caffeine consumption in healthy adults, pregnant women, adolescents, and children. Food Chem Toxicol 109:585-648. https://doi.org/10.1016/j.fct.2017.04.002
7. Ludden AB, O’Brien EM, Pasch KE (2017) Beliefs, behaviors, and contexts of adolescent caffeine use: a focus group study. Subst use misuse 52:1207-1218. https://doi.org/10.1080/10826084.2017. 1302957

8. Nehlig A (2016) Effects of coffee/caffeine on brain health and disease: what should I tell my patients? Pr Neurol 16:89-95. https://doi.org/10.1136/practneurol-2015-001162

9. Verster JC (2014) Caffeine consumption in children, adolescents and adults. Curr Drug Abus Rev 7:133-134

10. Williams M, Jarvis MF (1988) Adenosine antagonists as potential therapeutic agents. Pharmacol Biochem Behav 29:433-441

11. Daly JW, Fredholm BB (1998) Caffeine-an atypical drug of dependence. Drug alcohol depend 51:199-206. https://doi.org/10.1016/ s0376-8716(98)00077-5

12. Fredholm BB, Battig K, Holmen J et al (1999) Actions of caffeine in the brain with special reference to factors that contribute to its widespread use. Pharmacol Rev 51:83-133

13. Ribeiro JA, Sebastiao AM (2010) Caffeine and adenosine. J Alzheimers Dis 20(Suppl 1):S3-S15. https://doi.org/10.3233/ JAD-2010-1379

14. Fredholm BB, Yang J, Wang Y (2017) Low, but not high, dose caffeine is a readily available probe for adenosine actions. Mol asp med 55:20-25. https://doi.org/10.1016/j.mam.2016.11.011

15. Dunwiddie TV, Hoffer BJ, Fredholm BB (1981) Alkylxanthines elevate hippocampal excitability - evidence for a role of endogenous adenosine. Naunyn Schmiedebergs arch Pharmacol 316:326330. https://doi.org/10.1007/BF00501365

16. Sheth S, Brito R, Mukherjea D et al (2014) Adenosine receptors: expression, function and regulation. Int J Mol Sci 15:2024-2052. https://doi.org/10.3390/ijms15022024

17. Sebastião AM, Ribeiro JA (2009) Adenosine receptors and the central nervous system. Handb Exp Pharmacol 193:471-534

18. Ribeiro JA, Sebastiao AM, de Mendonca A (2002) Adenosine receptors in the nervous system: pathophysiological implications. Prog Neurobiol 68:377-392

19. Fredholm BB, IJ AP, Jacobson KA et al (2001) International Union of Pharmacology. XXV. Nomenclature and classification of adenosine receptors. Pharmacol Rev 53:527-552

20. Sebastiao AM, Ribeiro JA (1996) Adenosine A2 receptor-mediated excitatory actions on the nervous system. Prog Neurobiol 48:167189. https://doi.org/10.1016/0301-0082(95)00035-6

21. Li XX, Nomura T, Aihara H, Nishizaki T (2001) Adenosine enhances glial glutamate efflux via A2a adenosine receptors. Life Sci 68:1343-1350

22. Rodrigues RJ, Alfaro TM, Rebola N et al (2005) Co-localization and functional interaction between adenosine a $(2 \mathrm{~A})$ and metabotropic group 5 receptors in glutamatergic nerve terminals of the rat striatum. J Neurochem 92:433-441. https://doi.org/10.1111/j. 1471-4159.2004.02887.x

23. Rebola N, Canas PM, Oliveira CR, Cunha RA (2005) Different synaptic and subsynaptic localization of adenosine A2A receptors in the hippocampus and striatum of the rat. Neuroscience 132:893903. /https://doi.org/10.1016/j.neuroscience.2005.01.014

24. Mouro FM, Rombo DM, Dias RB, et al (2018) Adenosine A2A receptors facilitate synaptic NMDA currents in CA1 pyramidal neurons. Br J Pharmacol 175:4386-4397. /https://doi.org/10.1111/ bph.14497

25. Arendash GW, Cao C (2010) Caffeine and coffee as therapeutics against Alzheimer's disease. J Alzheimers dis 20 Suppl 1:S117-26. /https://doi.org/10.3233/JAD-2010-091249

26. de Mendonca A, Cunha RA (2010) Therapeutic opportunities for caffeine in Alzheimer's disease and other neurodegenerative disorders. J Alzheimers dis 20 Suppl 1:S1-2. /https://doi.org/10.3233/ JAD-2010-01420

27. Alhaider IA, Aleisa AM, Tran TT, Alzoubi KH, Alkadhi KA (2010) Chronic caffeine treatment prevents sleep deprivation- 
induced impairment of cognitive function and synaptic plasticity. Sleep 33:437-444

28. Costenla AR, Cunha RA, de Mendonca A (2010) Caffeine, adenosine receptors, and synaptic plasticity. J Alzheimers dis 20(Suppl 1):S25-S34. https://doi.org/10.3233/JAD-2010-091384

29. Faivre E, Coelho JE, Zornbach K, et al (2018) Beneficial effect of a selective adenosine A2A receptor antagonist in the APPswe/ PS1dE9 mouse model of Alzheimer's disease. Front Mol Neurosci 11:235. /https://doi.org/10.3389/fnmol.2018.00235

30. Lopes JP, Pliassova A, Cunha RA (2019) The physiological effects of caffeine on synaptic transmission and plasticity in the mouse hippocampus selectively depend on adenosine $\mathrm{A} 1$ and $\mathrm{A} 2 \mathrm{~A}$ receptors. Biochem Pharmacol 166:313-321. https://doi.org/10.1016/j. bcp.2019.06.008

31. Dore K, Stein IS, Brock JA et al (2017) Unconventional NMDA receptor signaling. J Neurosci 37:10800-10807. https://doi.org/10. 1523/JNEUROSCI.1825-17.2017

32. Vyklicky V, Korinek M, Smejkalova T et al (2014) Structure, function, and pharmacology of NMDA receptor channels. Physiol Res 63(Suppl 1):S191-S203

33. de Mendonca A, Sebastiao AM, Ribeiro JA (1995) Inhibition of NMDA receptor-mediated currents in isolated rat hippocampal neurones by adenosine A1 receptor activation. Neuroreport 6: $1097-1100$

34. Deng Q, Terunuma M, Fellin T, et al (2011) Astrocytic activation of A1 receptors regulates the surface expression of NMDA receptors through a Src kinase dependent pathway. Glia 59:1084-1093. /https://doi.org/10.1002/glia.21181

35. Rebola N, Lujan R, Cunha RA, Mulle C (2008) Adenosine A2A receptors are essential for long-term potentiation of NMDA-EPSCs at hippocampal mossy fiber synapses. Neuron 57:121-134. /https:// doi.org/10.1016/j.neuron.2007.11.023

36. Sarantis K, Tsiamaki E, Kouvaros S, et al (2015) Adenosine a(2) a receptors permit mGluR5-evoked tyrosine phosphorylation of NR2B (Tyr1472) in rat hippocampus: a possible key mechanism in NMDA receptor modulation. J Neurochem 135:714-726. /https://doi.org/10.1111/jnc.13291

37. Kouvaros S, Papatheodoropoulos C (2016) Major dorsoventral differences in the modulation of the local CA1 hippocampal network by NMDA, mGlu5, adenosine A2A and cannabinoid CB1 receptors. Neuroscience 317:47-64. /https://doi.org/10.1016/j. neuroscience.2015.12.059

38. Tebano MT, Martire A, Rebola N, et al (2005) Adenosine A2A receptors and metabotropic glutamate 5 receptors are co-localized and functionally interact in the hippocampus: a possible key mechanism in the modulation of N-methyl-d-aspartate effects. J Neurochem 95:1188-1200. /https://doi.org/10.1111/j.1471-4159. 2005.03455.x

39. Temido-Ferreira M, Ferreira DG, Batalha VL, et al (2018) Agerelated shift in LTD is dependent on neuronal adenosine A2A receptors interplay with mGluR5 and NMDA receptors. Mol psychiatry 1-25. /https://doi.org/10.1038/s41380-018-0110-9

40. Krania P, Dimou E, Bantouna M, et al (2018) Adenosine a $2 \mathrm{~A}$ receptors are required for glutamate mGluR5- and dopamine D1 receptor-evoked ERK1/2 phosphorylation in rat hippocampus: involvement of NMDA receptor. J Neurochem 145:217-231. /https:// doi.org/10.1111/jnc. 14268

41. Sebastiao AM, de Mendonca A, Moreira T, Ribeiro JA (2001) Activation of synaptic NMDA receptors by action potentialdependent release of transmitter during hypoxia impairs recovery of synaptic transmission on reoxygenation. J Neurosci 21:85648571

42. Zhang DS, Ren LM, Zhang L (2004) [Relation between adenosine A1 receptor and NMDA receptor on synaptic transmission in dentate gyrus of hippocampus]. Yao Xue Xue Bao 39:245-249
43. Costenla AR, Diogenes MJ, Canas PM et al (2011) Enhanced role of adenosine $\mathrm{a}(2 \mathrm{~A})$ receptors in the modulation of LTP in the rat hippocampus upon ageing. Eur J Neurosci 34:12-21. https://doi. org/10.1111/j.1460-9568.2011.07719.x

44. Cunha RA (2016) How does adenosine control neuronal dysfunction and neurodegeneration? J Neurochem 139:1019-1055. https:// doi.org/10.1111/jnc. 13724

45. Ribeiro FF, Xapelli S, Miranda-Lourenco C et al (2016) Purine nucleosides in neuroregeneration and neuroprotection. Neuropharmacology 104:226-242. https://doi.org/10.1016/j. neuropharm.2015.11.006

46. Dong ZS, Cao ZP, Shang YJ et al (2019) Neuroprotection of cordycepin in NMDA-induced excitotoxicity by modulating adenosine A1 receptors. Eur J Pharmacol 853:325-335. https://doi.org/ 10.1016/j.ejphar.2019.04.015

47. Jeronimo-Santos A, Vaz SH, Parreira S et al (2015) Dysregulation of TrkB receptors and BDNF function by amyloid-beta peptide is mediated by Calpain. Cereb cortex 25:3107-3121. https://doi.org/ 10.1093/cercor/bhu105

48. Ferreira DG, Temido-Ferreira M, Miranda H V, et al (2017) Alphasynuclein interacts with $\operatorname{Pr} P(C)$ to induce cognitive impairment through mGluR5 and NMDAR2B. Nat Neurosci 20:1569-1579. /https://doi.org/10.1038/nn.4648

49. Horvat A, Zorec R, Vardjan N (2016) Adrenergic stimulation of single rat astrocytes results in distinct temporal changes in intracellular $\mathrm{Ca}(2+)$ and cAMP-dependent PKA responses. Cell calcium 59:156-163. https://doi.org/10.1016/j.ceca.2016.01.002

50. Dunwiddie TV, Masino SA (2001) The role and regulation of adenosine in the central nervous system. Annu rev Neurosci 24:31-55. https://doi.org/10.1146/annurev.neuro.24.1.31

51. Corradetti R, Lo Conte G, Moroni F et al (1984) Adenosine decreases aspartate and glutamate release from rat hippocampal slices. Eur J Pharmacol 104:19-26. https://doi.org/10.1016/00142999(84)90364-9

52. Creager R, Dunwiddie T, Lynch G (1980) Paired-pulse and frequency facilitation in the CA1 region of the in vitro rat hippocampus. J Physiol 299:409-424. https://doi.org/10.1113/jphysiol.1980. sp013133

53. Zucker RS, Regehr WG (2002) Short-term synaptic plasticity. Annu rev Physiol 64:355-405. https://doi.org/10.1146/annurev. physiol.64.092501.114547

54. Ongini E, Dionisotti S, Gessi S et al (1999) Comparison of CGS 15943, ZM 241385 and SCH 58261 as antagonists at human adenosine receptors. Naunyn Schmiedebergs arch Pharmacol 359:7-10. https://doi.org/10.1007/pl00005326

55. Ongini E, Monopoli A, Cacciari B, Baraldi PG (2001) Selective adenosine A2A receptor antagonists. Farmaco 56:87-90. https:// doi.org/10.1016/s0014-827x(01)01024-2

56. Zocchi C, Ongini E, Conti A, Monopoli A, Negretti A, Baraldi PG, Dionisotti S (1996) The non-xanthine heterocyclic compound SCH 58261 is a new potent and selective A2a adenosine receptor antagonist. J Pharmacol Exp Ther 276:398-404

57. Iacobucci GJ, Popescu GK (2017) NMDA receptors: linking physiological output to biophysical operation. Nat rev Neurosci 18:236249. https://doi.org/10.1038/nrn.2017.24

58. Sebastião AM, Ribeiro JA (2015) Neuromodulation and metamodulation by adenosine: impact and subtleties upon synaptic plasticity regulation. Brain res 1621:102-113. https://doi.org/10. 1016/j.brainres.2014.11.008

59. Daly JW, Fredholm BB (1998) Caffeine-an atypical drug of dependence. Drug Alcohol Depend 51:199-206

60. Simons SB, Caruana DA, Zhao M, Dudek SM (2012) Caffeineinduced synaptic potentiation in hippocampal CA2 neurons. Nat Neurosci 15:23-25. https://doi.org/10.1038/nn.2962

61. Martín ED, Buño W (2003) Caffeine-mediated presynaptic longterm potentiation in hippocampal CA1 pyramidal neurons. $\mathrm{J}$ 
Neurophysiol 89:3029-3038. https://doi.org/10.1152/jn.00601. 2002

62. McKinney RA (2010) Excitatory amino acid involvement in dendritic spine formation, maintenance and remodelling. J Physiol 588: 107-116. https://doi.org/10.1113/jphysiol.2009.178905

63. Manent JB, Represa A (2007) Neurotransmitters and brain maturation: early paracrine actions of GABA and glutamate modulate neuronal migration. Neuroscientist 13:268-279. https://doi.org/10. $1177 / 1073858406298918$

64. Schlett K (2006) Glutamate as a modulator of embryonic and adult neurogenesis. Curr Top Med Chem 6:949-960

65. Traynelis SF, Wollmuth LP, McBain CJ et al (2010) Glutamate receptor ion channels: structure, regulation, and function. Pharmacol rev 62:405-496. https://doi.org/10.1124/pr.109.002451

66. Allene C, Cossart R (2010) Early NMDA receptor-driven waves of activity in the developing neocortex: physiological or pathological network oscillations? J Physiol 588:83-91. https://doi.org/10.1113/ jphysiol.2009.178798

67. Pereira-Figueiredo D, Brito R, Araújo DSM, et al (2020) Caffeine exposure ameliorates acute ischemic cell death in avian developing retina. Purinergic signal 16:41-59. /https://doi.org/10.1007/ s11302-020-09687-1

68. Silva CG, Métin C, Fazeli W, et al (2013) Adenosine receptor antagonists including caffeine alter fetal brain development in mice. Sci Transl med 5:197ra104-197ra104. /https://doi.org/10.1126/ scitranslmed.3006258

69. Diógenes MJ, Assaife-Lopes N, Pinto-Duarte A et al (2007) Influence of age on BDNF modulation of hippocampal synaptic transmission: interplay with adenosine A2A receptors. Hippocampus 17:577-585. https://doi.org/10.1002/hipo.20294

70. Dumas TC, Foster TC (1998) Late developmental changes in the ability of adenosine A1 receptors to regulate synaptic transmission in the hippocampus. Brain Res Dev Brain Res 105:137-139

71. Coppi E, Pugliese AM, Stephan H et al (2007) Role of P2 purinergic receptors in synaptic transmission under normoxic and ischaemic conditions in the CA1 region of rat hippocampal slices. Purinergic signal 3:203-219. https://doi.org/10.1007/s11302-0069049-4

72. Fusco I, Cherchi F, Catarzi D et al (2019) Functional characterization of a novel adenosine $\mathrm{A} 2 \mathrm{~B}$ receptor agonist on short-term plasticity and synaptic inhibition during oxygen and glucose deprivation in the rat CA1 hippocampus. Brain res bull 151:174-180. https://doi.org/10.1016/j.brainresbull.2019.05.018

73. Markram H, Segal M (1992) The inositol 1,4,5-trisphosphate pathway mediates cholinergic potentiation of rat hippocampal neuronal responses to NMDA. J Physiol 447:513-533. https://doi.org/10. 1113/jphysiol.1992.sp019015

74. Clark KA, Randall AD, Collingridge GL (1994) A comparison of paired-pulsed facilitation of AMPA and NMDA receptor-mediated excitatory postsynaptic currents in the hippocampus. Exp brain res 101:272-278. https://doi.org/10.1007/bf00228747

75. Fontinha BM, Delgado-García JM, Madroñal N et al (2009) Adenosine a $(2 \mathrm{~A})$ receptor modulation of hippocampal CA3-CA1 synapse plasticity during associative learning in behaving mice. Neuropsychopharmacology 34:1865-1874. https://doi.org/10. 1038/npp.2009.8

76. Pedata F, Pepeu G, Spignoli G (1984) Biphasic effect of methylxanthines on acetylcholine release from electrically-stimulated brain slices. Br J Pharmacol 83:69-73. https://doi.org/10.1111/j. 1476-5381.1984.tb10120.x

77. Spignoli G, Pedata F, Pepeu G (1984) A1 and A2 adenosine receptors modulate acetylcholine release from brain slices. Eur $\mathrm{J}$ Pharmacol 97:341-342. https://doi.org/10.1016/0014-2999(84) 90475-8

Publisher's note Springer Nature remains neutral with regard to jurisdictional claims in published maps and institutional affiliations. 